\title{
Mobilidade urbana e as áreas verdes do Município de João Pessoa, Paraíba: perspectivas para uma cidade sustentável
}

\author{
Hélder Formiga Fernandes*, Reinaldo Farias Paiva de Lucena
}

Programa de Pós-Graduação em Desenvolvimento e Meio Ambiente. Centro de Ciências Exatas e da Natureza. Universidade Federal da Paraíba. Campus I. João Pessoa-PB, Brasil (CEP 58051-900). *E-mail: onorte20@uol.com.br.

Resumo. O objetivo desta pesquisa foi avaliar a Mobilidade Urbana e as Áreas Verdes do Município de João Pessoa, na perspectiva do desenvolvimento de uma cidade sustentável. 0 embasamento teórico da pesquisa foi elaborado com o auxílio da norma ABNT NBR ISO 37.120:2017, que dá os parâmetros necessários para avaliar o desenvolvimento sustentável de comunidades. Visitas periódicas foram realizadas na Secretaria de Mobilidade Urbana (SEMOB) e na Secretaria de Meio Ambiente (SEMAM) do Município de João Pessoa, bem como na Superintendência de Administração do Meio Ambiente (SUDEMA) para a obtenção de documentos oficiais para análise, bem como foram realizadas visitas em vários setores da cidade para mapear as áreas verdes do município e avaliar os seus principais Programas de Mobilidade Urbana. Também foram elaborados questionários, os quais foram respondidos por pessoas escolhidas aleatoriamente. Foi constatado que o Município de João Pessoa vem realizando Projetos de Infraestrutura Urbano Sustentável, intervenções em vários setores da cidade, que incluem capeamento asfáltico, alargamento de vias, instalação de ciclovias, rebaixamento de calçadas, faixas exclusivas para ônibus, melhorando a capacidade de mobilidade da população. Embora sejam notórios os esforços da edilidade para facilitar a mobilidade urbana no Município de João Pessoa, ao serem questionados, a maioria dos respondentes informaram que o excesso de veículos é a maior dificuldade para os deslocamentos nas vias. Além disso, a má qualidade dos ônibus e o tempo de espera superior a 30 minutos desestimulam o uso deste tipo de transporte, fazendo com que João Pessoa seja uma cidade que utiliza o modelo automobilístico-rodoviário urbano para a mobilidade da população. Com relação às áreas verdes, a Mata do Buraquinho, o Parque Arruda Câmara e a Praça da Independência são frequentados por uma grande parcela da população. A maioria dos respondentes reconheceram que o Município de João Pessoa como uma cidade verde, estando preparado para receber o título de cidade sustentável. Conclui-se que o Município de João Pessoa está conduzindo projetos de mobilidade urbana e nas áreas verdes, transformando-a numa cidade sustentável.
Recebido:

$27 / 11 / 2017$

Aceito:

$02 / 04 / 2018$

Publicado:

30/04/2018

Acesso aberto

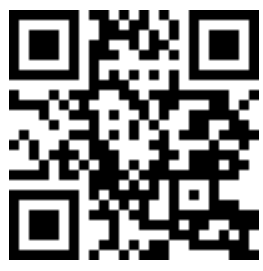

ORCID

0000-0002-0370-0673

Hélder Formiga Fernandes

D 0000-0003-4775-7775 Reinaldo Farias Paiva de Lucena 
Palavras-chave: Políticas Públicas; Sustentabilidade; Cidades; Paraíba.

Abstract. The objective of this research was to evaluate the Urban Mobility and the Green Areas of the Municipality of João Pessoa, in the perspective of the development of a sustainable city. The theoretical basis of the research was elaborated with the aid of the norm ABNT NBR ISO 37.120:2017, which gives the necessary parameters to evaluate the sustainable development of communities. Periodic visits were made to the Secretaria de Mobilidade Urbana (SEMOB) and the Secretaria de Meio Ambiente (SEMAM) of the Municipality of João Pessoa, as well as the Superintendência de Administração de Meio Ambiente (SUDEMA) to obtain official documents for analysis, how visits were made in various sectors of the city to map out the green areas of the municipality and evaluate its main Urban Mobility Programs. Questionnaires were also developed, which were answered by randomly chosen people. It was verified that the Municipality of João Pessoa has been carrying out Projects of Sustainable Urban Infrastructure, interventions in various sectors of the city, including asphaltic capping, widening of roads, installation of cycle paths, lowering of pavements, exclusive lanes for buses, improving mobility of the population. Although the efforts of the city council to facilitate urban mobility in the Municipality of João Pessoa are notorious, most respondents informed that the excess of vehicles is the greatest difficulty for road dislocations. In addition, the poor quality of the buses and the waiting time of more than 30 minutes discourage the use of this type of transportation, making João Pessoa a city that uses the urban automobile-road model for the mobility of the population. Regarding the green areas, Mata do Buraquinho, Parque Arruda Câmara and the Praça da Independência are frequented by a large portion of the population. The majority of the respondents recognized that the Municipality of João Pessoa as a green city, being prepared to receive the title of sustainable city. It is concluded that the Municipality of João Pessoa is conducting urban mobility projects and in the green areas, transforming it into a sustainable city.

Keywords: Public Policies; Sustainability; Cities; Paraíba.

\section{Introdução}

Quando do surgimento das primeiras aglomerações urbanas, as cidades eram localizadas próximas aos recursos naturais propícios para o seu desenvolvimento, fazendo com que o homem primitivo desenvolvesse técnicas que lhes ajudasse a controlar e gerenciar os recursos disponíveis, do modo como foi observado nos agrupamentos ribeirinhos localizados ao longo do Rio Amarelo (circa 1.550 a.C.) e o Rio Tigre e o Rio Eufrates (circa 3.500 a.C.) na Região da Mesopotâmia (Brumes, 2001).

A crescente urbanização, aliada ao desenvolvimento da industrialização concentrada nas cidades, a agricultura mecanizada prioritariamente em sistema de monocultura, a formação das 
pastagens, a intensa exploração de recursos naturais (carvão mineral, petróleo, recursos hídricos, minérios), ocasionando inclusive a poluição, alterou substancialmente e modo irreversível as feições da Terra.

Invariavelmente, o desenvolvimento econômico das cidades está sendo obtido em detrimento das condições e qualidade de vida da população, ocorrendo da mesma forma, tanto nas pequenas, quanto nas médias e grandes cidades, tendo em vista que os problemas ambientais são iguais, aumentando de acordo com o tamanho e o índice populacional de cada uma delas (Stipp e Stipp, 2004).

A partir do século XIX, o avanço da urbanização aprofundou-se, provocando a carência de infraestrutura, resultando nas condições atuais das cidades, que concentram, cada vez mais, um grande número da população mundial (Ximenes, 2011).

O número de pessoas habitando as áreas urbanas está constantemente aumentando, ao ponto da ONU (2012) apontar que até 2050 a proporção de pessoas vivendo nas cidades chegará, dos $53 \%$ atuais, a 70\%. Deste modo, praticamente todas as cidades da Terra tem experimentado uma série de fatores insustentáveis para a manutenção do equilíbrio do meio ambiente e da saúde da população.

Metade da humanidade atualmente vive em cidades, no Brasil, segundo a Rede Nossa São Paulo (2012), a população urbana chega a $85 \%$. No Município de João Pessoa, de acordo com o IBGE (2017), 77\% da população vive em território urbanizado. As dificuldades em se manter o equilíbrio espacial, social e ambiental aumentam de acordo com o crescimento populacional e de tamanho das cidades, sendo este último considerado o principal fator limitante.

0 crescimento demográfico desenfreado, o uso predatório dos recursos naturais, a geração de grandes volumes de resíduos, a supressão de áreas verdes, o consumo excessivo de energia (Gonçalves e Silva, 2016; Sell e Haupenthal, 2016) e o tráfego intenso de veículos automotores (Verhetsel, 2001), além da formação das ilhas de calor (Yu et al., 2017) são alguns exemplos desses fatores, que acabam comprometendo a harmonia entre a sociedade e a utilização dos recursos naturais dentro das cidades, havendo, como produto final, consequências na qualidade de vida humana e no meio ambiente em torno das cidades.

Devido às ações humanas, principalmente por meio do uso e apropriação indevido do espaço urbano, é que os problemas ambientais surgem nas cidades. Assim, desmatamentos, impermeabilização dos solos, poluição das águas e do ar, modificações indesejáveis nos ecossistemas, principalmente os manguezais, as nascentes dos rios e a região ripária, o efeito estufa e a destruição da camada de ozônio, bem como a produção e disposição inadequada dos resíduos sólidos contribuem para o desequilíbrio ecológico nas cidades.

As consequências globais sobre a dramática aglomeração urbana representam importantes desafios para a gestão pública (Weiss et al., 2015). Para compatibilizar o crescimento econômico e o desenvolvimento da população com a utilização dos recursos naturais, surgiu o conceito de desenvolvimento sustentável, que se traduz em um conjunto de estratégicas que procuram o uso racional dos recursos naturais, que na comprometa a utilização desses mesmos recursos pelas gerações futuras (Lacerda, 2017).

O desenvolvimento sustentável pretende satisfazer as necessidades da geração atual sem comprometer a possibilidade ou a capacidade de suprimento das gerações futuras (Hamel e Grubba, 2016). Portanto, para que sejam implantadas medidas de sustentabilidade em áreas urbanas é necessário um planejamento no qual se definam estratégias que contemplem as esferas social, econômica e ambiental, 
para que a sociedade possa se desenvolver em equilíbrio com o meio ambiente.

As esferas social, econômica e ambiental presentes no desenvolvimento sustentável convergem com maior intensidade nas cidades, portanto, é importante que elas tenham sua gestão e planejamento com bases na sustentabilidade. As áreas verdes e a mobilidade urbana são pontos cruciais nos centros urbanos, visto que englobam as três esferas do desenvolvimento sustentável.

Visando à busca de alternativas para a execução de projetos urbanos sustentáveis, através de investimentos maciços nas, a partir de 2013, áreas de mobilidade, meio ambiente, habitação, lazer e cultura, o Município de João Pessoa realizou operação de crédito, em parceria com o Banco Interamericano de Desenvolvimento (BID), para a implantação do Programa de Desenvolvimento Urbano Integrado e Sustentável do Município de João Pessoa (João Pessoa, 2014; Oliveira-e-Silva, 2016-2017).

Frente a esse estado questiona-se como se dá a mobilidade urbana das áreas verdes no Município de João Pessoa, sob a perspectiva do desenvolvimento da cidade sustentável.

Considerando a pergunta norteadora da pesquisa, traçou-se como objetivo geral avaliar a mobilidade urbana e as áreas verdes do Município de João Pessoa, na perspectiva do desenvolvimento de uma cidade sustentável, e como objetivos específicos (a) analisar os instrumentos legais promotores de sustentabilidade no Município de João Pessoa, correlacionando com sua gestão, (b) analisar a percepção da população do Município de João Pessoa com relação à qualidade de vida, áreas verdes urbanas e mobilidade urbana, e (c) mapear as áreas verdes e praças públicas no Município de João Pessoa.

\section{Fundamentação teórica}

Existem importantes ligações entre a urbanização das cidades, as transformações econômicas e as condições ambientais, e justamente por esses três fatores serem intrínsecos é que ocorre a geração de problemas ambientais variados. Segundo Boareto (2008) o processo de urbanização verificado nos países em desenvolvimento, principalmente na última metade do século passado, resultou em grandes concentrações populacionais em um número reduzido de cidades, o que tornou evidente o conflito existente entre pessoas de diferentes classes pela apropriação e uso dos espaços públicos, distribuindo-se de modo desigual pelas cidades.

Até meados dos anos 1980 em diversos países o desenvolvimento econômico a qualquer custo era considerado mais importante do que os impactos ambientais que este pudessem causar (Goldemberg e Lucon, 2007). Essa política desenvolvimentista levou um grande número de migração para as cidades urbanizadas, sem que estas estivessem preparadas. As consequências ambientais foram desastrosas, tanto pelo aumento dos resíduos domésticos e industriais, quanto pela contaminação dos corpos d'água doce e salgada (Mucelin e Bellini, 2008; Fraga et al., 2013), e pela diminuição da qualidade de vida da população. Esta visão desenvolvimentista foi sofrendo alterações nos anos 1990, quando começaram a se efetivar os esforços mundiais para amenizar os efeitos antrópicos na natureza a partir do desenvolvimento do conceito da sustentabilidade.

De acordo com Vieira (2012), a partir da segunda metade do século XIX começou-se a perceber a degradação ambiental e suas catastróficas consequências em nível planetário, 
dando origem a estudos e às primeiras reações para atingir métodos de diminuição dos danos ambientais. Tais estudos lançaram subsídios para a concepção da ideia de que o desenvolvimento deve estar diretamente ligado à preservação ambiental.

\section{Sustentabilidade e as políticas públicas: reflexões}

Quem deu o primeiro alerta sobre a finitude dos recursos naturais e sua consequência para a população humana foi Thomas Malthus, já em 1798, em seu "Ensaio Sobre o Princípio da População" (Malthus, 1798), o qual defendia que o principal problema mundial da época era que a existência de um excesso na população e parcos recursos naturais para o seu sustento. Entretanto, de acordo com Dias (1993) e Romeiro (2012), o desenvolvimento sustentável perpassou por vários processos históricos, iniciando com a pesquisadora Rachel Carson, que em 1962 publicou o livro "Primavera Silenciosa" (Carson, 2010), impulsionando o movimento ambientalista através da promoção de uma série de eventos sobre o meio ambiente, sobre os problemas relacionados ao uso indiscriminado de pesticidas e sobre as consequências da poluição ambiental. Em seu profético livro, a cientista chamado a atenção para o uso indiscriminado de agrotóxicos que poderia provocar o desaparecimento de certos animais, como insertos e os pássaros, causando o que ela chamou de "primavera silenciosa".

Em 1966, tem-se a formação do Clube de Roma, fundado pelo industrial italiano Aurelio Peccei e pelo cientista escocês Alexander King, e composto por pessoas ilustres com o intuito de discutir as crises na humanidade, como 0 controle do crescimento populacional, a diminuição do consumo a partir da mudança na mentalidade das pessoas, a preservação dos recursos não renováveis, bem como a criação do Relatório do Clube de Roma "Os Limites do Crescimento" ou Relatório de
Meadows, em 1972 (Meadows et al., 1972), que tratava sobre problemas acerca do futuro do desenvolvimento da humanidade relacionados ao meio ambiente.

Em 1972, em Estocolmo na Suécia, aconteceu a I Conferência das Nações Unidas sobre o Ambiente Urbano, na qual foram discutidos o crescimento zero e o crescimento a qualquer custo; e multinacionais e poluição como preço do progresso no Brasil e na Índia. Havendo também a criação do Programa das Nações Unidas para o Meio Ambiente.

Em 1977 aconteceu a I Conferência Intergovernamental sobre Educação Ambiental, em Tbilisi, na Geórgia, onde foram definidos conceitos, finalidades, objetivos, princípios e estratégias da Educação Ambiental. No Brasil a Polícia Militar orienta o MEC a falar sobre ecologia, pois a educação ambiental é tratada como perigosa e revolucionária.

Em 1987 houve o II Congresso Mundial da Educação Ambiental, em Moscou na Rússia. Daí surgiu o Relatório de Brundtland ou "Nosso Futuro Comum"; houve a validação das definições discutidas em Tbilisi e a definição de Desenvolvimento Sustentável como "o desenvolvimento que satisfaz as necessidades presentes, sem comprometer a capacidade das gerações futuras de suprir suas próprias necessidades".

Em 1992 ocorreu a Conferência das Nações Unidas sobre o Meio Ambiente e o Desenvolvimento, conhecida também como ECO'92 e Rio'92, que discutiu a promoção do desenvolvimento sustentável em diferentes escalas e houve a criação de diversos documentos oficiais, como Agenda 21, convenções da diversidade biológica, desertificação e mudanças climáticas; foi criado o Tratado de Educação Ambiental para Sociedades Sustentáveis e Responsabilidade Global.

Em 1997, foi discutido e negociado, em Kyoto no Japão, o Protocolo de Kyoto, que é um tratado 
com vistas à diminuição da emissão de gases responsáveis pelo aquecimento global através de ações como a reforma nos setores de energia e transportes, promoção e uso de fontes de energia renovável, limitação a emissão de metano, proteção de florestas e demais sequestradores de carbono.

Em 2002, ocorreu a Cúpula Mundial do Desenvolvimento Sustentável, conhecido como Rio+10, em Johanesburgo, na África do Sul, que avaliou as mudanças ocorridas dez anos após a Rio'92 e teve uma abordagem mais social do que ambiental, visto pautas como erradicação da miséria e da fome e acesso à água e a energias renováveis.

Em 2012, novamente no Rio de Janeiro, ocorreu a Conferência das Nações Unidas sobre o Desenvolvimento Sustentável, conhecida como Rio+20, que teve o objetivo de renovar o compromisso político com o desenvolvimento sustentável, através da avaliação do progresso e das lacunas na implementação das decisões tomadas na Conferência das Nações Unidas sobre o Meio Ambiente e o Desenvolvimento de 1992, a Eco'92, e adotadas pelos principais países, bem como tratar de temas novos e emergentes.

A participação do Brasil nas Conferências das Nações Unidas sobre o Meio Ambiente e o Desenvolvimento (Eco'92 e Rio+20) fez com que fossem traçados vários marcos políticos no Brasil, com o desenvolvimento de políticas públicas voltadas para as questões sociais, mas estimuladas e influenciadas pelos movimentos internacionais, visando a mudanças numa cultura que agora seria baseada na participação e envolvimento social (Rocha et al. 2017).

O desenvolvimento sustentável percorreu no Brasil, ainda de acordo com Dias (1993), Romeiro (2012) e Moura; Hirata (2013), os seguintes passos históricos, a começar em 1970, o Ministério da Educação e Cultura (MEC) começa a discutir a educação relacionada ao meio ambiente e a disciplina "Ciências Ambientais" tornou-se obrigatória para os Cursos de Engenharia.

Em 1988, a Constituição Federal, art. 225, inciso VI, determinou que o Poder Público como responsável pela promoção da Educação Ambiental em todos os níveis de ensino.

Em 1991, foi publicada a Portaria MEC no 678, determinando que a Educação Ambiental deva ser estendida para todos os currículos nos diferentes níveis de modalidade de ensino, de modo transversal.

Em 1992, o MEC realizou o workshop sobre Educação Ambiental, na RIO'92.

Em 1994, houve a aprovação do PRONEA - Programa Nacional de Educação Ambiental, que deveria ser executado conjuntamente pelo Ministério da Educação (MEC), pelo Ministério do Meio Ambiente (MMA), pelo Ministério da Cultura (MINC) e pelo Ministério da Ciência e da Tecnologia (MCT), objetivando subsidiar estes ministérios para desenvolver ações de educação ambiental diversos níveis e modalidades de ensino.

Em 1997, houve a I Conferência Nacional de Educação Ambiental, em Brasília, que culminou com a "Declaração Brasília", consolidando sugestões de diretrizes e políticas para a Educação Ambiental no Brasil.

Em 1998, foi sancionada a Lei $\mathrm{n}^{-}$ 9.605, que dispõe sobre as sanções penais e administrativas derivadas de condutas e atividades lesivas ao meio ambiente (Brasil, 1998).

Em 1999, foi sancionada a Lei no 9.795, que institui a Política Nacional de Educação Ambiental (BRASIL, 1999).

Em 2000, foi sancionada a Lei no 9.985, que instituiu o Sistema Nacional de Unidades de Conservação da Natureza (Brasil, 2000).

Em 2001, foi sancionada a Lei $\mathrm{n}$ 응 10.257, que regulamentou os artigos 182 e 183, da Constituição Federal de 1988, também conhecida como Estatuto das Cidades (Brasil, 2001), que descriminou 
uma série de diretrizes gerais que, caso sejam observadas pelo poder público, possuem grande potencial para tornar as cidades equilibradas com 0 meio ambiente. Assim consagra o art. $2^{2}$ da referida norma, in verbis:

Art. 2o A política urbana tem por objetivo ordenar o pleno desenvolvimento das funções sociais da cidade e da propriedade urbana, mediante as seguintes diretrizes gerais:

I - garantia do direito a cidades sustentáveis, entendido como o direito à terra urbana, à moradia, ao saneamento ambiental, à infraestrutura urbana, ao transporte e aos serviços públicos, ao trabalho e ao lazer, para as presentes e futuras gerações;

II - gestão democrática por meio da participação da população e de associações representativas dos vários segmentos da comunidade na formulação, execução e acompanhamento de planos, programas e projetos de desenvolvimento urbano;

III - cooperação entre os governos, a iniciativa privada e os demais setores da sociedade no processo de urbanização, em atendimento ao interesse social;

IV - planejamento do desenvolvimento das cidades, da distribuição espacial da população e das atividades econômicas do Município e do território sob sua área de influência, de modo a evitar e corrigir as distorções do crescimento urbano e seus efeitos negativos sobre o meio ambiente;

$\mathrm{V}$ - oferta de equipamentos urbanos e comunitários, transporte e serviços públicos adequados aos interesses e necessidades da população e às características locais;

VI - ordenação e controle do uso do solo, de forma a evitar:

a) a utilização inadequada dos imóveis urbanos;

b) a proximidade de usos incompatíveis ou inconvenientes;

c) o parcelamento do solo, a edificação ou o uso excessivos ou inadequados em relação à infraestrutura urbana;

d) a instalação de empreendimentos ou atividades que possam funcionar como pólos geradores de tráfego, sem a previsão da infra-estrutura correspondente;

e) a retenção especulativa de imóvel urbano, que resulte na sua subutilização ou não utilização;

f) a deterioração das áreas urbanizadas;

g) a poluição e a degradação ambiental;

h) a exposição da população a riscos de desastres. (Incluído pela Lei $\mathrm{n}^{\mathbf{0}}$ 12.608, de 2012)

VII - integração e complementaridade entre as atividades urbanas e rurais, tendo em vista o desenvolvimento socioeconômico do Município e do território sob sua área de influência;

VIII - adoção de padrões de produção e consumo de bens e serviços e de expansão urbana compatíveis com os limites da sustentabilidade ambiental, social e econômica do Município e do território sob sua área de influência;

IX - justa distribuição dos benefícios e ônus decorrentes do processo de urbanização;

$X$ - adequação dos instrumentos de política econômica, tributária e financeira e dos gastos públicos aos objetivos do desenvolvimento urbano, de modo a privilegiar os investimentos geradores de bemestar geral e a fruição dos bens pelos diferentes segmentos sociais;

XI - recuperação dos investimentos do Poder Público de que tenha resultado a valorização de imóveis urbanos;

XII - proteção, preservação e recuperação do meio ambiente natural e construído, do patrimônio cultural, histórico, artístico, paisagístico e arqueológico;

XIII - audiência do Poder Público municipal e da população interessada nos processos de implantação de empreendimentos ou atividades com efeitos potencialmente negativos sobre o meio ambiente natural 
ou construído, o conforto ou a segurança da população;

XIV - regularização fundiária e urbanização de áreas ocupadas por população de baixa renda mediante o estabelecimento de normas especiais de urbanização, uso e ocupação do solo e edificação, consideradas a situação socioeconômica da população e as normas ambientais;

XV - simplificação da legislação de parcelamento, uso e ocupação do solo e das normas edilícias, com vistas a permitir a redução dos custos e o aumento da oferta dos lotes e unidades habitacionais;

XVI - isonomia de condições para os agentes públicos e privados na promoção de empreendimentos e atividades relativos ao processo de urbanização, atendido o interesse social.

XVII - estímulo à utilização, nos parcelamentos do solo e nas edificações urbanas, de sistemas operacionais, padrões construtivos e aportes tecnológicos que objetivem a redução de impactos ambientais e a economia de recursos naturais. (Incluído pela Lei $\mathrm{n}$ o 12.836 , de 2013)

XVIII - tratamento prioritário às obras e edificações de infraestrutura de energia, telecomunicações, abastecimento de água e saneamento. (Incluído pela Lei $\mathrm{n}^{\mathrm{o}} 13.116$, de 2015)

Posteriormente, a Lei $\mathrm{n}$ o 12.587/2012 (Brasil, 2012), que instituiu a Política Nacional de Mobilidade Urbana, ao estipular através de princípios, diretrizes e instrumentos fundamentais para o processo de transição.

Art. 5 A Política Nacional de Mobilidade Urbana está fundamentada nos seguintes princípios:

I - acessibilidade universal;

II - desenvolvimento sustentável das cidades, nas dimensões socioeconômicas e ambientais;

III - equidade no acesso dos cidadãos ao transporte público coletivo;
IV - eficiência, eficácia e efetividade na prestação dos serviços de transporte urbano;

V - gestão democrática e controle social do planejamento e avaliação da Política Nacional de Mobilidade Urbana;

VI - segurança nos deslocamentos das pessoas;

VII - justa distribuição dos benefícios e ônus decorrentes do uso dos diferentes modos e serviços;

VIII - equidade no uso do espaço público de circulação, vias e logradouros; e

IX - eficiência, eficácia e efetividade na circulação urbana.

Art. 6ㅇ A Política Nacional de Mobilidade Urbana é orientada pelas seguintes diretrizes:

I - integração com a política de desenvolvimento urbano e respectivas políticas setoriais de habitação, saneamento básico, planejamento e gestão do uso do solo no âmbito dos entes federativos;

II - prioridade dos modos de transportes não motorizados sobre os motorizados e dos serviços de transporte público coletivo sobre o transporte individual motorizado;

III - integração entre os modos e serviços de transporte urbano;

IV - mitigação dos custos ambientais, sociais e econômicos dos deslocamentos de pessoas e cargas na cidade;

$\mathrm{V}$ - incentivo ao desenvolvimento científico-tecnológico e ao uso de energias renováveis e menos poluentes;

VI - priorização de projetos de transporte público coletivo estruturadores do território e indutores do desenvolvimento urbano integrado; e

VII - integração entre as cidades gêmeas localizadas na faixa de fronteira com outros países sobre a linha divisória internacional.

Art. 7ํ A Política Nacional de Mobilidade Urbana possui os seguintes objetivos: 
I-reduzir as desigualdades e promover a inclusão social;

II - promover o acesso aos serviços básicos e equipamentos sociais;

III - proporcionar melhoria nas condições urbanas da população no que se refere à acessibilidade e à mobilidade;

IV - promover o desenvolvimento sustentável com a mitigação dos custos ambientais e socioeconômicos dos deslocamentos de pessoas e cargas nas cidades; e

V - consolidar a gestão democrática como instrumento e garantia da construção contínua do aprimoramento da mobilidade urbana.

Foram estes marcos políticos, aliados à preocupação com a qualidade de vida da população, que impulsionaram os municípios brasileiros a promoverem ações que favorecem a mobilidade urbana mais efetiva e a criação de áreas verdes públicas.

\section{Cidades sustentáveis: mobili- dade urbana e áreas verdes}

Historicamente, as cidades surgiram de forma não planejada, muitas vezes em torno de um corpo d'água, o qual abastecia a população. De acordo com Martins e Cândido (2015), o surgimento e crescimento das cidades de forma desordenada e/ou não planejada, não conseguem atender à demanda da população urbana em relação à infraestrutura e aos serviços prestados, tornando-se deste modo fonte de inúmeros problemas.

Considerando que as cidades são sistemas complexos que dependem de fatores externos para a sua manutenção (Bettencourt, 2015), a sustentabilidade, que conceitualmente estimula a autossuficiência no que implica o consumo e a supressão de resíduos no mesmo espaço, pode proporcionar um novo modelo de cidades sustentáveis, transformando os locais, devendo ter a ordem e o controle quanto ao uso do solo, visando a evitar a degradação dos recursos naturais, através de um conjunto de medidas que englobem o bem-estar social, econômico e ambiental (Stoffel e Colognese, 2015).

Para que uma determinada cidade alcance a sustentabilidade é necessário que aja um planejamento urbano que contemple objetivos bem definidos a médio e longo prazo, conciliando a visão utilitária exploratória dos recursos naturais com a sua organização racional, equilibrando as demandas de crescimento com a necessidade de proteção do meio ambiente (Garzon, 2013). Além disso, o planejamento também deve ser capaz de prever a distribuição do desenvolvimento econômico dentro de uma área determinada para alcançar objetivos sociais, permitindo a criação de um marco de associação entre os governos municipais, o setor privado e o público em general (Honda et al., 2015; Silva, 2017).

De acordo com Braga (2006), a sustentabilidade urbana é uma temática de interesse recente, tendo-se consolidado no decorrer da década de 1990, impulsionado pela mudança do enfoque das questões ambientais dos anos 1980 que deu uma guinada para o estudo da sustentabilidade.

A urbanização das cidades aumentou também a motorização populacional, resultando em congestionamentos e na disputa dos diversos tipos de transporte, sejam eles de pessoas, prestação de serviços ou mercadorias (Topp, 1995; Thomson, 1998). Neste sentido, a mobilidade urbana sustentável é a principal chave para a resolução desta problemática.

A mobilidade urbana sustentável, de acordo com Campos e Ramos (2005), pode ser compreendida como a promoção na igualdade dos possíveis deslocamentos, facilitando o acesso a diversas atividades de uma região, a fim de reduzir o consumo de energia e a poluição ambiental em relação aos meios de transporte e, consequentemente, promovendo uma melhoria e eficiência 
nos recursos aplicados aos meios de transporte.

Andrade e Jerônimo (2015) afirmam que, a partir do desenvolvimento das cidades, os elementos naturais são cada vez mais suprimidos da paisagem, no entanto, a busca pela inserção de árvores no espaço urbano pode refletir numa procura por métodos de reconciliação, ou de busca pela manutenção de uma qualidade de vida na cidade.

As áreas verdes são espaços, aí considerados as praças, os jardins públicos e os parques urbanos, bem como canteiros centrais e trevos presentes em vias públicas, onde há vegetação predominantemente arbórea (Loboda e Angelis, 2005), podendo ser privadas, potencialmente coletivas e públicas, são elementos essenciais para a reconciliação do homem com a natureza.

Segundo Bonametti (2003) e Bargos e Matias (2011) a arborização dos centros urbanos de forma correta provoca não só a transformação morfológica de áreas já ocupadas, mas também promove a incorporação de novos espaços às áreas urbanas, podendo inclusive valorizar espaços contemporâneos das cidades.

0 plantio de árvores em áreas urbanas possui uma série de vantagens que influenciam diretamente na melhoria da qualidade de vida da população, como a criação de microclimas, proporcionando uma temperatura mais agradável aos ambientes urbanizados; 0 aparecimento de uma fauna dispersora e polinizadora, que vai acarretar numa maior diversificação da flora já existente; a redução da poluição atmosférica e sonora; e, por fim, o aumento da autoestima da população devido ao sentimento de satisfação que um ambiente arborizado pode causar (Schuch, 2006). Além disso, a arborização urbana garante a integração dos ambientes habitados às regiões do seu entorno, o que proporciona uma continuidade na cadeia biológica, bem como das características climáticas e ambientais, sendo assim evitadas as ilhas de calor, os desertos biológicos e o desconforto ambiental caracterizado por cidades sem proteção vegetal adequada (Brun et al., 2007).

Para Bonametti (2003), o aumento da população e da urbanização tem motivado a administração pública a demonstrar um maior interesse na arborização urbana, o que vem sido fortalecido pela vontade da comunidade, principalmente através do discurso ecológico que está incorporado em espaços urbanizados, apontando para uma melhor qualidade de vida, progresso e desenvolvimento urbano. Ainda de acordo com Bonametti (2003), é indispensável que haja a efetivação da política pública em pesquisar como a arborização das vias urbanas pode preencher de forma correta os espaços da cidade, para depois serem propostas medidas adequadas à melhoria funcional e estética destas áreas.

Embora o aumento da qualidade ambiental influencie de forma positiva na qualidade de vida da população de uma área urbana, de acordo com Carcereri et al. (2016), o compromisso de uma cidade com a qualidade ambiental deve ser refletido na adoção de políticas públicas para a conservação da natureza.

\section{Metodologia}

\section{Local da pesquisa}

0 estudo foi realizado no Município de João Pessoa, capital do Estado da Paraíba, que pertence à Microrregião de João Pessoa e à Mesorregião da Mata Paraibana, com clima do tipo Am, segundo a classificação climática de Köppen (Köppen, 1900; Alvares et al., 2014), com temperatura média anual em torno dos $25,2^{\circ} \mathrm{C}$ e pluviosidade média anual de $1.888 \mathrm{~mm}$, com chuvas frequentes e abundantes de março a agosto, e alberga uma população estimada em 811.598 habitantes (IBGE, 2017).

A Região Metropolitana de João Pessoa, com população estimada em 
1.268.360 (IBGE, 2017), foi instituída pela Lei Complementar no 59/2003 (Paraíba, 2003), formada inicialmente pelos Municípios de Bayeux, Cabedelo, Conde, Cruz do Espírito Santo, João Pessoa, Lucena, Mamanguape, Rio Tinto e Santa Rita, foram incluídos os Municípios de Alhandra, Pitimbu e Caaporã, pela Lei Complementar no 90/2009 (Paraíba, 2009a), e o Município de Pedras de Fogo, pela Lei Complementar no 93/2009 (Paraíba, 2009b), sendo excluído o Município de Mamanguape, com a criação da Região Metropolitana do Vale do Mamanguape, pela Lei Complementar no 116/2013 (Paraíba, 2013).

Obtenção dos dados da
pesquisa
0 embasamento teórico da
pesquisa foi elaborado com o auxílio da norma ABNT NBR ISO 37.120:2017 (ABNT, 2017), que dá os parâmetros necessários para avaliar o desenvolvimento sustentável de comunidades, com a propositura de indicadores para os serviços urbanos e a qualidade de vida, levando-se consideração os temas transporte (seção 18) e o planejamento urbano (seção 19).

Visitas periódicas foram realizadas na Secretaria de Mobilidade Urbana (SEMOB) e na Secretaria de Meio Ambiente (SEMAM) do Município de João Pessoa, bem como na Superintendência de Administração do Meio Ambiente (SUDEMA) para a obtenção de documentos oficiais para ara análise.

\section{Mapeamento das áreas verdes}

Com auxílio de GPS, realizou-se um mapeamento das áreas verdes e bosques do Município de João Pessoa (Jardim Botânico/Mata do Buraquinho, Parque Zoobotânico, praças públicas, resquício de mata da UFPB), com o intuito de determinar sua dimensão territorial.

\section{Mobilidade urbana}

Foram analisados os principais programas em execução no Município de
João Pessoa (implantação de ciclovias, faixas exclusivas para transporte público), no intuito de verificar os seus desempenhos.

Com auxílio de GPS, foi mapeada os rebaixamentos das três principais artérias do Município de João Pessoa (Avenida Beira Rio, Avenida Epitácio Pessoa e Avenida Ruy Carneiro), para se verificar o cumprimento da legislação referente à mobilidade urbana.

\section{Percepção ambiental}

Foram elaborados questionários semi-estruturados com perguntas abertas e fechadas referentes à mobilidade urbana e às áreas verdes do Município de João Pessoa.

Através de abordagem aleatória, entre novembro e dezembro de 2017, e os questionários foram apresentados à população de João Pessoa. Deste modo, servidores lotados em órgãos públicos (municipais, estaduais e federais), que tratam da questão ambiental e de mobilidade urbana, membros da população usuários do Ponto dos Cem Réis, Lagoa do Parque Solon de Lucena, Shopping Center Manaíra, orla marítima, Universidade Federal da Paraíba, Escolas Estaduais e do Centro Universitário de João Pessoa (UNIPÊ). Assim, pretendeuse que o questionário pudesse ser respondido por pessoas de vários setores de João Pessoa, de modo que as respostas fossem as mais significativas.

Toda a pesquisa foi avaliada pelo Comitê de Ética em Pesquisa, do Centro de Ciências da Saúde, da Universidade Federal da Paraíba (Processo CAAE no 79175317.0.0000.5188) e apenas foram aplicados após a sua aprovação.

\section{Resultados}

\section{Mobilidade urbana}

Através do Programa de Desenvolvimento Urbano Integrado e Sustentável, o Município de João Pessoa vem buscando cumprir com a determinação constitucional de realizar projetos de infraestrutura urbano 
sustentável (Oliveira-e-Silva, 20162017), que vem favorecendo eficiência da mobilidade urbana, não apenas direcionadas para os pedestres, mas também para os usuários de transportes coletivos de passageiros, bem como para os ciclistas.

Ao longo da Avenida Epitácio Pessoa e da Avenida José Américo de Almeida (Beira Rio) foram instaladas ciclovias (Figura 1-A) que permitem o acesso rápido de ciclistas do Centro da Cidade até o setor de praias da capital, passando por diversos bairros.

Também foram instalados rebaixamentos das calçadas para que as pessoas com deficiência possam se locomover mais eficientemente (Figura 1-B).

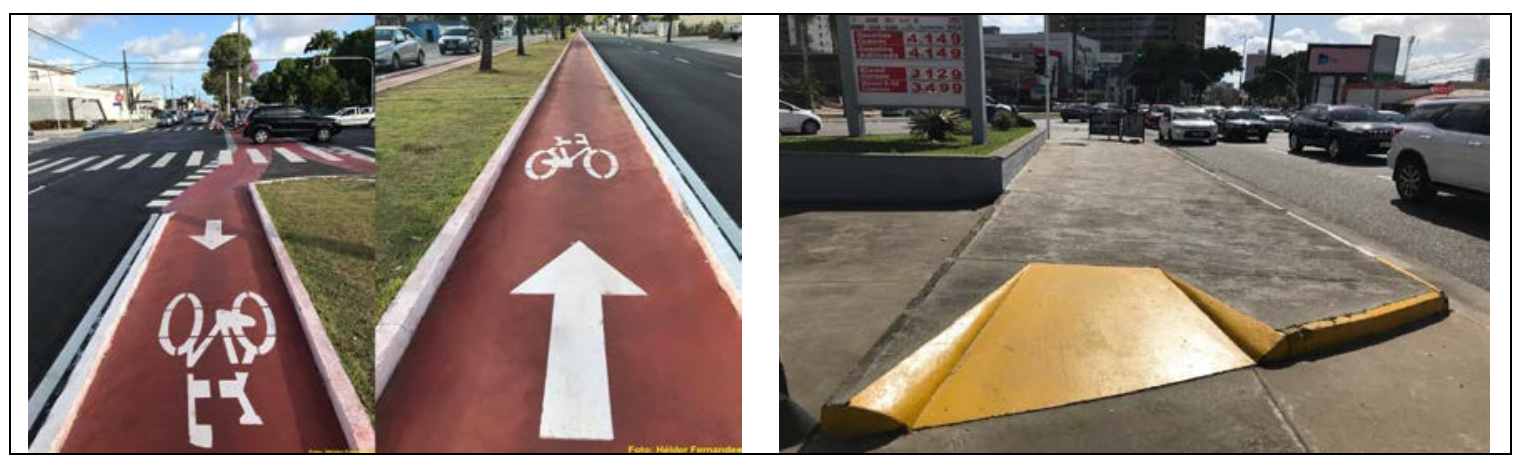

Figura 1. (A). Ciclovia ao longo da Avenida José Américo de Almeida (Beira Rio), em 2017. (b) Calçada rebaixada para acesso de pessoas com deficiência, na Av. Ruy Carneiro. 2018.
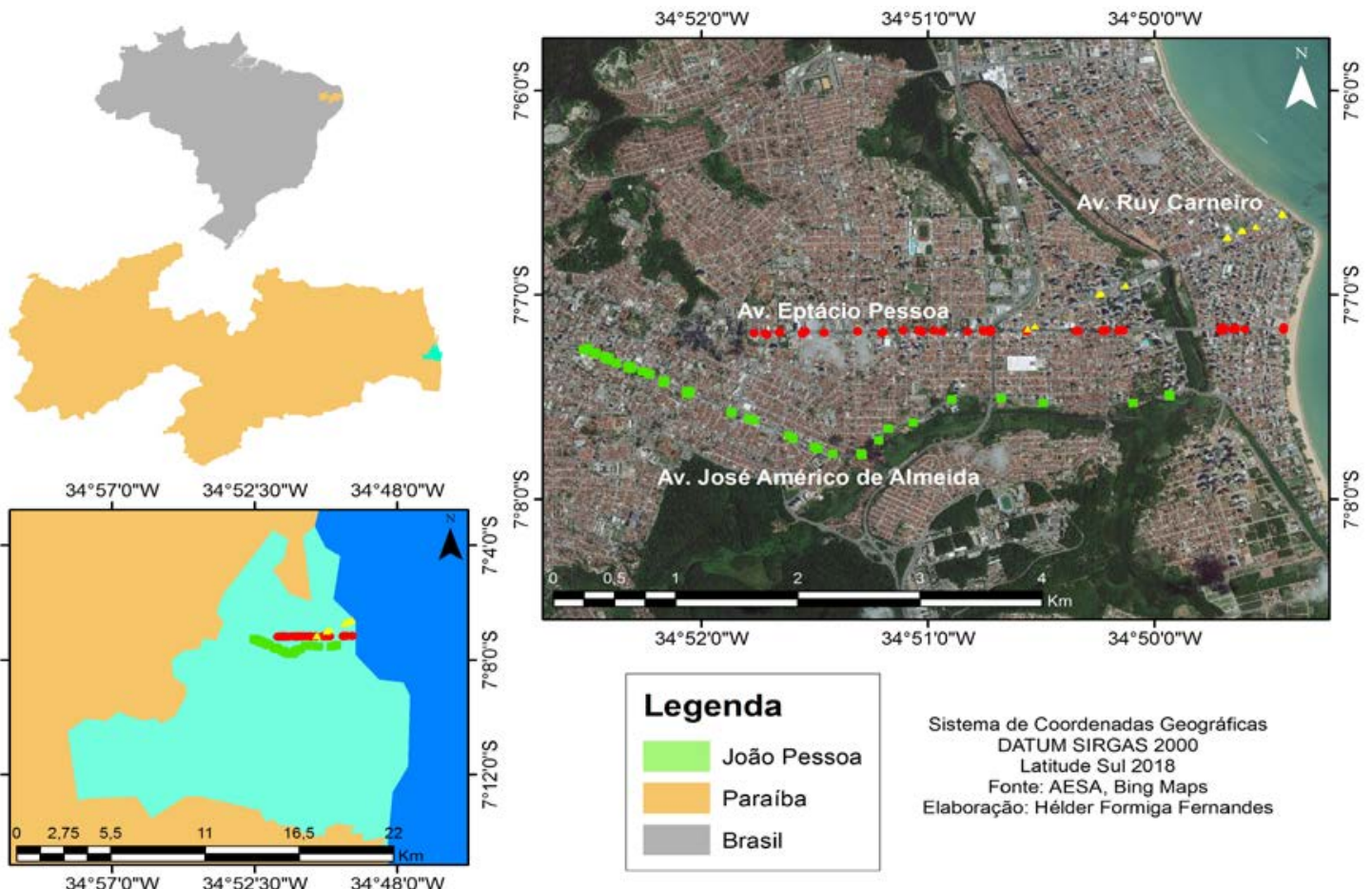

Figura 2. Mapeamento das calçadas rebaixadas para acesso de pessoas com deficiência, nas Av. Rui Carneiro, Epitácio Pessoa e José Américo de Almeida (Beira Rio). 2018. Foto: Hélder Fernandes. 
Nas maiores artérias da Cidade de João Pessoa, foram instalados 45 pontos de rebaixamento para cadeirantes na Avenida Epitácio Pessoa, 13 na Avenida Ruy Carneiro, e 51 na Avenida José Américo de Almeida (Beira Rio) (Figura 2).

Para facilitar o tráfego de transporte coletivo de passageiros, foram instaladas faixas exclusivas para ônibus de transportes coletivos, ao longo da Avenida Dom Pedro II (Figura 3-A, B, C) e da Avenida Epitácio Pessoa, além de serem instaladas passarelas na BR-230, na altura do km 24, e na Avenida Dom Pedro II (Figura 3-A).

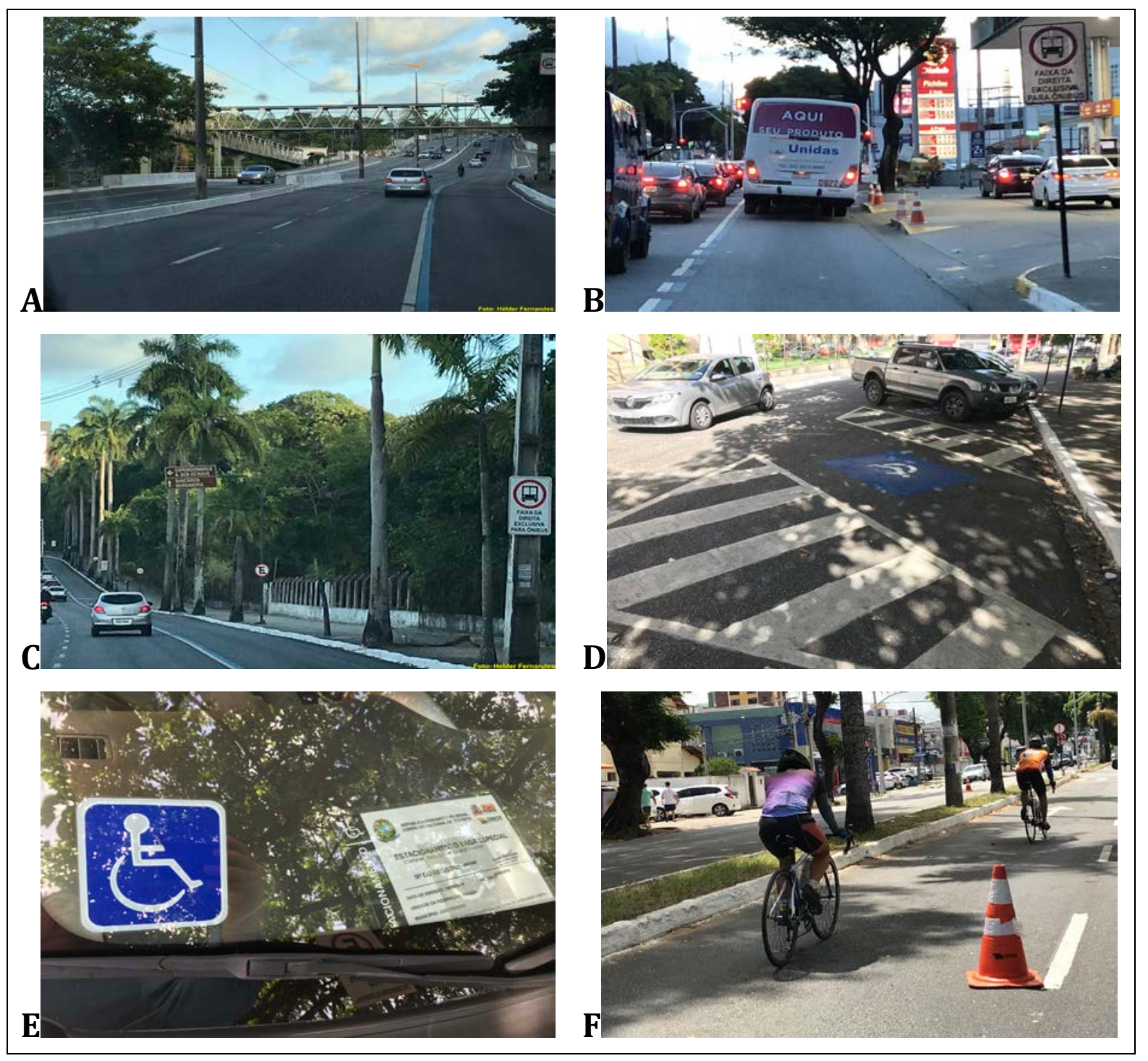

Figura 3. (A) Faixa exclusiva para ônibus na Avenida Dom Pedro II. 2017. (B) Faixa exclusiva para ônibus na Avenida Epitácio Pessoa - 2018. (C) Faixa exclusiva para ônibus de transportes coletivos, ao longo da Avenida Dom Pedro II. 2017. (D) Passarela de pedestres na Avenida Dom Pedro II. 2017. (E) Estacionamento reservado às pessoas com deficiência, na Praça João Pessoa. 2018. (G) Credencial que permite às pessoas com deficiência estacionarem nas vagas reservadas em João Pessoa. 2018. (F) Faixa exclusiva para ciclistas aos domingos na Avenida Epitácio Pessoa, em João Pessoa. 2017. 
Também é comum no Município de João Pessoa a presença de vagas nos estacionamentos públicos e nos estabelecimentos comerciais, de vagas destinadas às pessoas com deficiência e para os idosos (Figura 3-D), mediante a apresentação de cartão, distribuído pela Secretaria de Mobilidade Urbana (SEMOB) (Figura 3-E).

Outra importante ação da Prefeitura Municipal de João Pessoa é reservar, todos os domingos, ao longo da Avenida Epitácio Pessoa, uma faixa exclusiva para a utilização dos ciclistas (Figura 3-F).

\section{Áreas verdes}

Devido ao número acentuado de árvores existentes, a Assembleia Legislativa da Paraíba concedeu, por meio da Lei no 6.818, de 16 de novembro de 1999, o título de Cidade Verde ao Município de João Pessoa (Paraíba, 1999).

Certamente, os fatores decisivos para que a Assembleia Legislativa da Paraíba concedesse este título de Cidade Verde ao Município de João Pessoa, reside no fato da presença da Mata do Buraquinho, uma área com cerca de 515 ha, que contém um dos maiores resquícios de Mata Atlântica em perímetro urbano, onde, além de ter sido declarada de preservação permanente, pelo Decreto no 98.181/1989 (Brasil, 1989), está instalado o Jardim Botânico da Paraíba (Figura 4-A, B), criado pelo Decreto no 21.264, de 28 de agosto de 2000 (Paraíba, 2000), e a unidade de conservação de proteção integral sobreposta Refúgio da Vida Silvestre da Mata do Buraquinho, criada pelo Decreto no 35.195, de 23 de julho de 2014.

Além desta área bem arborizada no Município de João Pessoa ainda pode ser encontrada praças, como a Praça da Independência (Figura 5-A, B) e o Parque Zoobotânico Arruda Câmara (Bica) (Figura 5-C, D).

Estes espaços são regularmente utilizados, principalmente aos sábados, domingos e feriado, como áreas de lazer e contemplação da Natureza, que permitem à população de João Pessoa interagir com o meio natural.

Vale ressaltar que, para proteger a arborização urbana do Município de João Pessoa, a Lei Complementar $\mathrm{n}$ o 029/2002, que instituiu o Código Municipal de Meio Ambiente (João Pessoa, 2002), capitula como infração ambiental, causar, de qualquer forma, danos às praças e/ou largos e às áreas verdes (art. 221, inciso XVIII). Ademais, a Lei $\mathrm{n}$-12.101/2011 que instituiu o Sistema Municipal de Áreas Protegidas de João Pessoa, é um importante instrumento que estabelece critérios e normas para a criação, implantação e gestão das unidades de conservação da natureza e dos parques municipais da cidade.

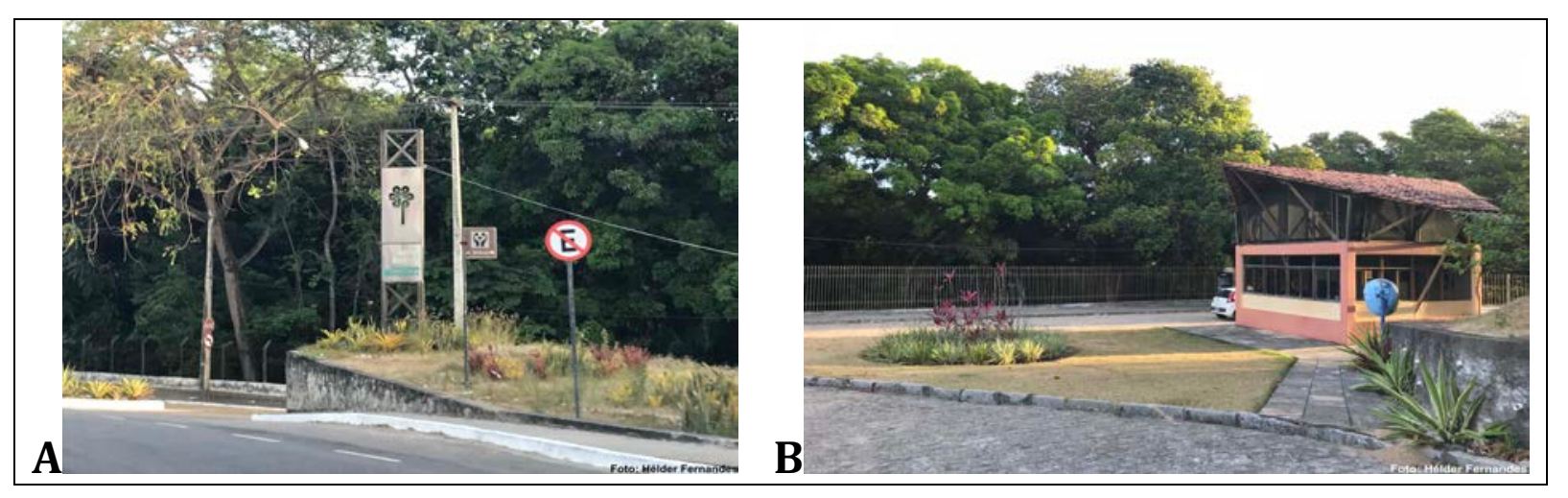

Figura 4. Jardim Botânico de João Pessoa, Paraíba. 2017. 


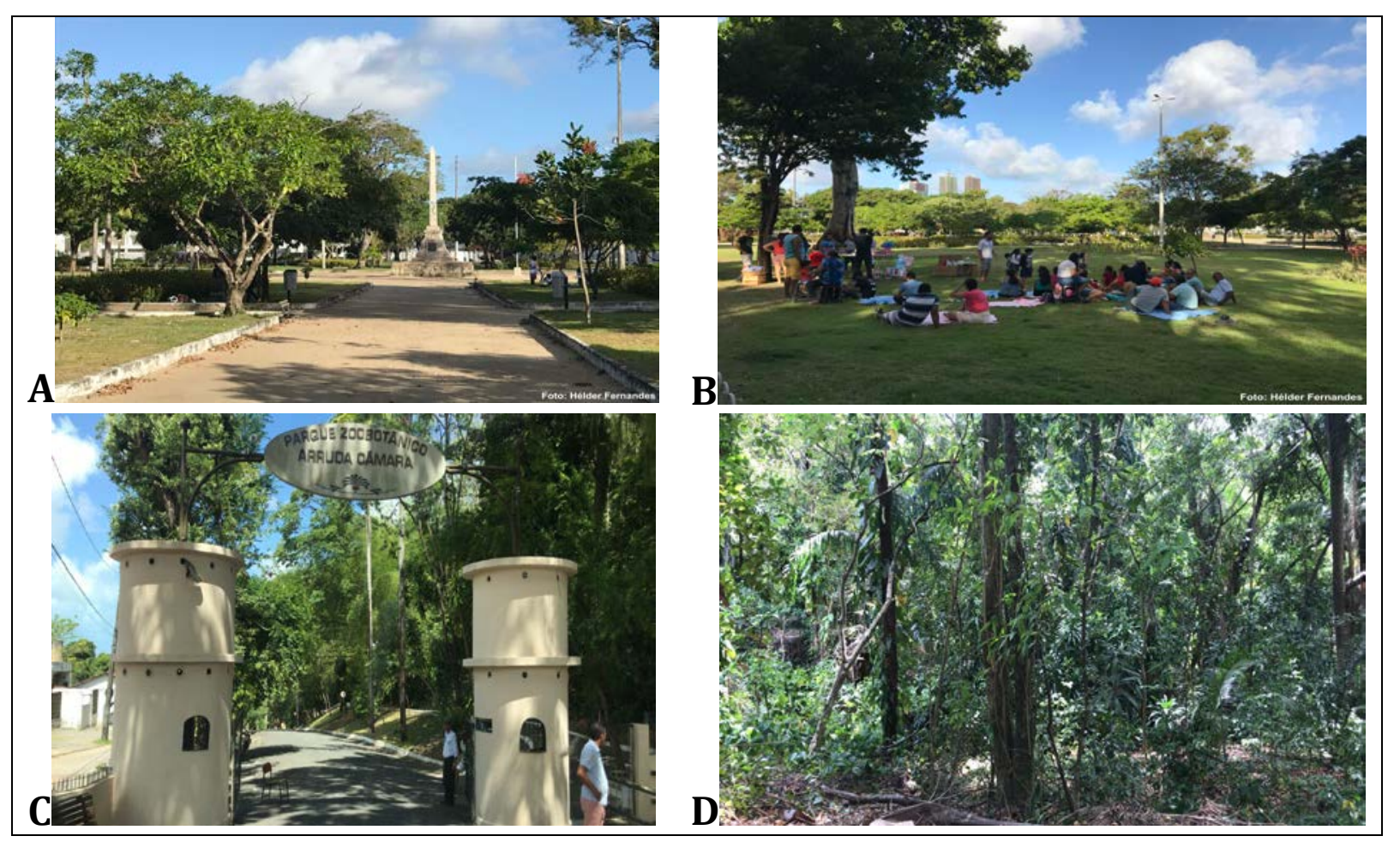

Figura 5. (A) Praça da Independência. 2017. (B) Praça da Independência. 2017. (C) Parque Zoobotânico Arruda Câmara. 2017. (D) Parque Zoobotânico Arruda Câmara.

\section{Percepção dos moradores}

Responderam os questionários 444 pessoas do sexo masculino e 464 do sexo feminino, totalizando 908 indivíduos. Destes, a maioria (38\%) pertencem à faixa etária de até 18 anos, seguido de $31 \%$ entre 19 a 29 anos (Figura 6-A).

Em relação à renda mensal e considerando $\mathrm{o}$ salário mínimo de $\mathrm{R} \$ 937,00,30 \%$ recebem de 1 a 2 salários, e $29 \%$ recebem até um salário mínimo (Figura 6-B).

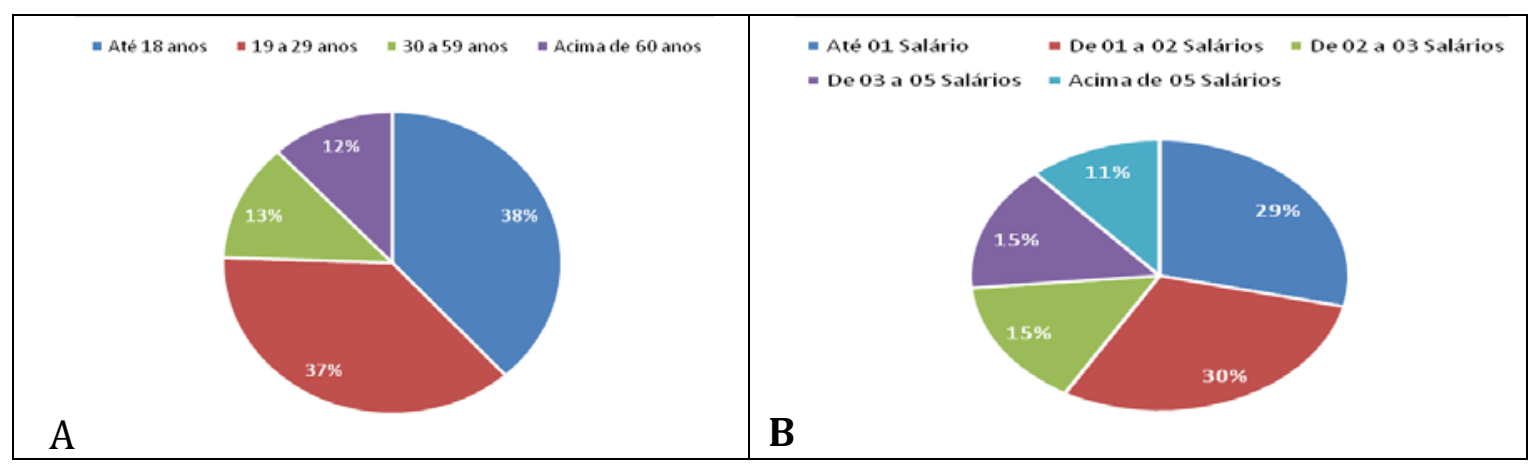

Figura 16. (A) Faixa etária dos participantes da pesquisa. (B) Renda mensal da população estudada. 


\section{Mobilidade urbana}

Os participantes da pesquisa mencionaram as localidades onde residem, incluindo bairros de João Pessoa e das cidades próximas (vide material suplementar ao artigo on line).

Dos 908 participantes, 618 mencionaram que estudam, 228 não estudam e 62 não responderam a este questionamento. Segue a relação e o quantitativo onde os 336 estudam (vide material suplementar).

Foi questionado também quantos dos pesquisados trabalham, então 588 responderam que trabalham, 278 não trabalham, 2 são aposentados, e 40 não responderam (vide material suplementar).

Em relação à média dos deslocamentos por dia, 26\% mencionaram que realizam 2 ou 3 deslocamentos, $23 \%$ realizam mais de 5 deslocamentos (Figura 6).

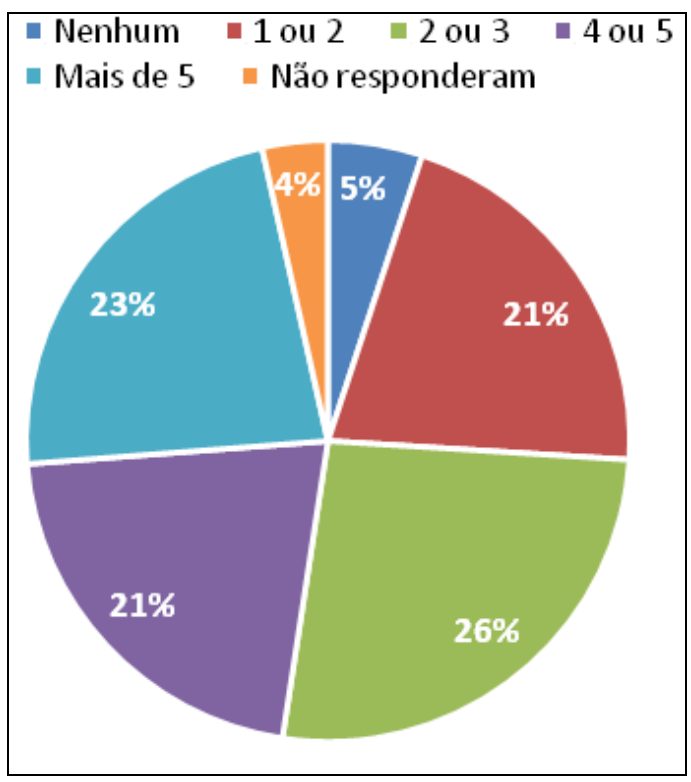

Figura 6. Quantitativo da média de deslocamentos dos indivíduos pesquisados.

Em relação ao principal motivo para os deslocamentos, a maioria respondeu que é o trabalho (22\%); em seguida, é a saúde (20\%) (Figura 7).

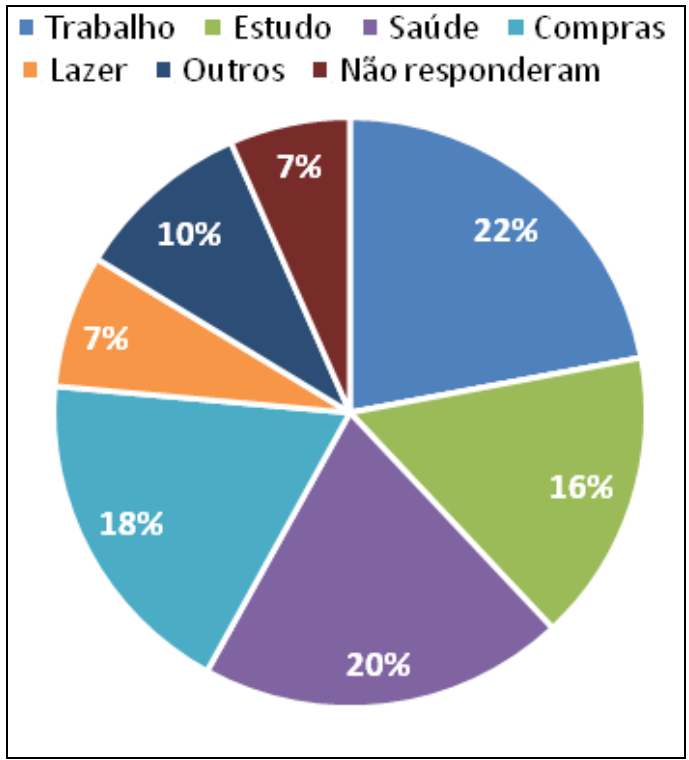

Figura 7. Principal motivo para os deslocamentos para a população estudada.

A maioria dos participantes da pesquisa afirmaram que utilizam ônibus municipal (35\%) como principal meio para deslocamentos, seguido de carro próprio (24\%) (Figura 8).

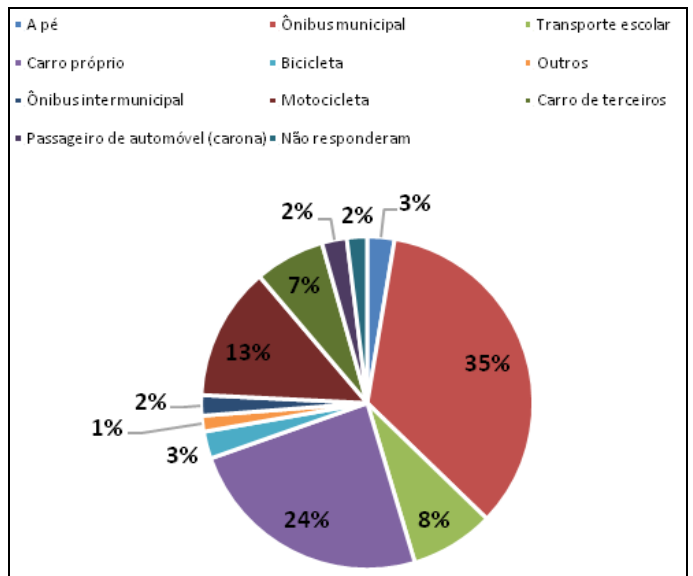

Figura 8. Principal meio de transporte para deslocamentos para os participantes da pesquisa.

Quanto aos que automóvel próprio, $39 \%$ utilizam todos os dias, seguido de $27 \%$ que utilizam de 1 a 3 dias por semana (Figura 9). 


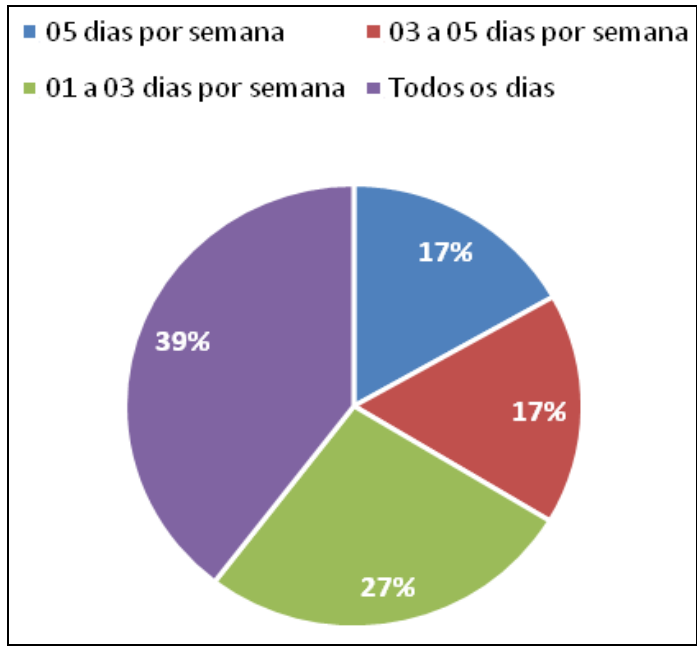

Figura 9. Frequência de utilização de automóvel próprio por parte dos participantes da pesquisa.

Em relação às principais dificuldades para o deslocamento encontrada no dia-a-dia, a maioria dos participantes da pesquisa respondeu que é o excesso de veículos nas ruas (31\%), seguido da lentidão nas principais avenidas (19\%) (Figura 10).

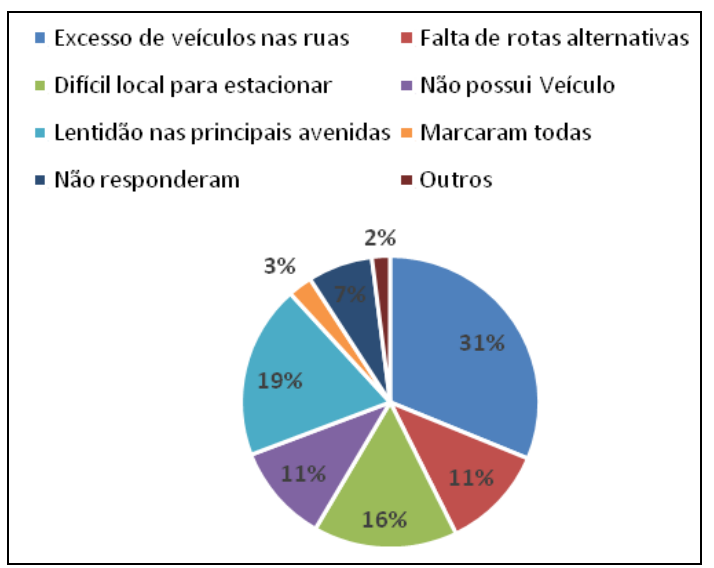

Figura 10. Principais dificuldades para os deslocamentos encontradas no dia-a-dia pelos participantes da pesquisa.

Quando perguntados a respeito do motivo que os impede da não utilização do ônibus, 39\% afirmaram que não utilizam devido à má qualidade das vias, seguido de $22 \%$ dos participantes que não utilizam devido à falta de segurança nos ônibus (Figura 11).

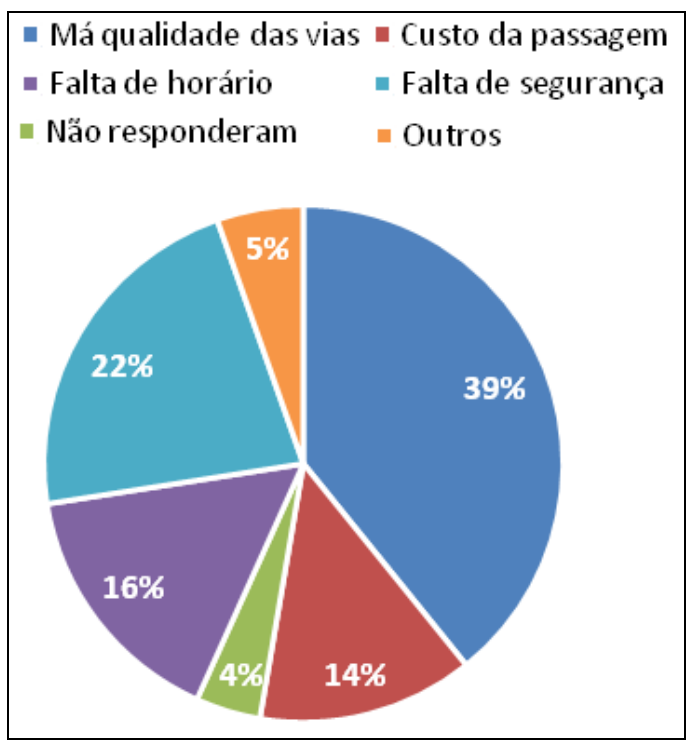

Figura 11. Motivo porque os participantes não utilizam o ônibus como meio de transporte para deslocamento.

Em relação à qualidade das linhas de ônibus, a maioria dos participantes da pesquisa mencionaram que é ruim (27\%), seguido de boa (25\%) (Figura 12).

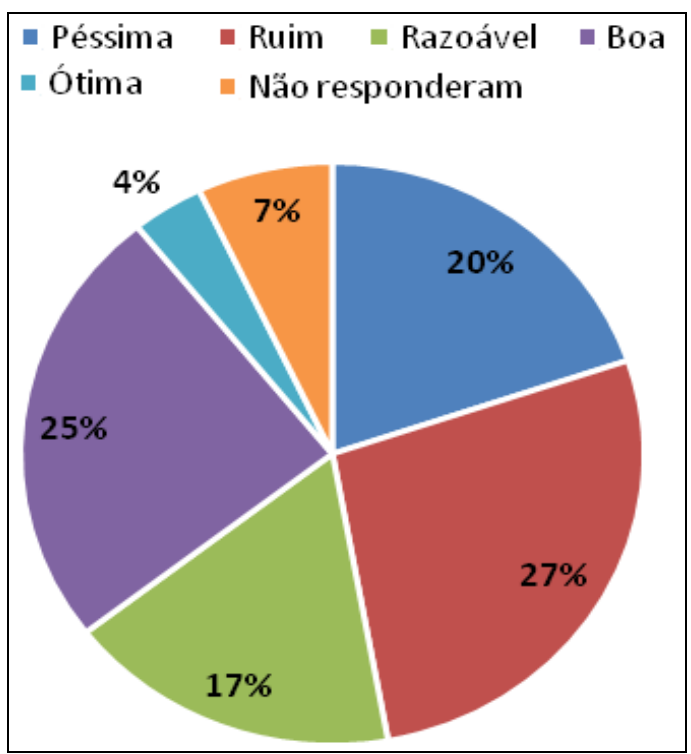

Figura 12. Qualidade das linhas de ônibus na visão dos participantes da pesquisa. 
Em relação ao tempo médio de espera dos ônibus, $35 \%$ dos participantes afirmaram que é entre 20 a 30 minutos, seguido de $34 \%$ que afirmam que demora acima de 30 minutos (Figura 13).

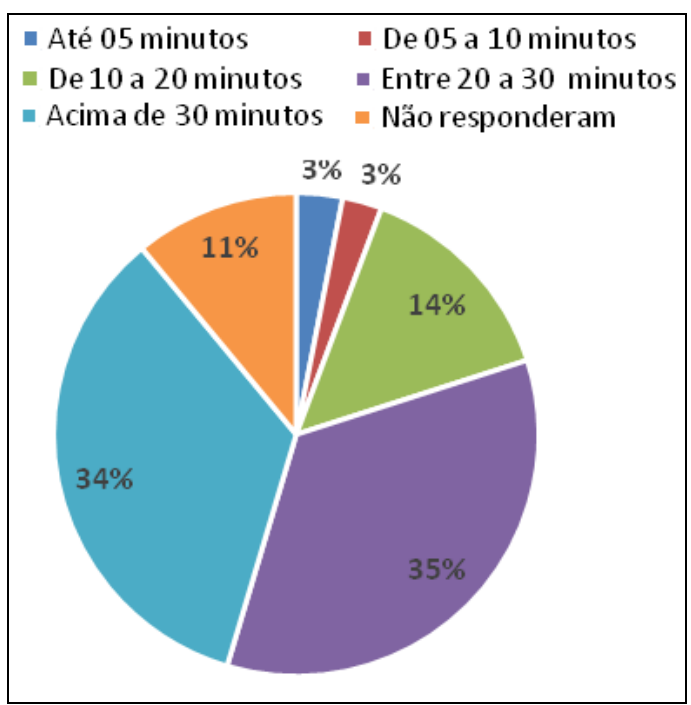

Figura 13. Tempo médio de espera dos ônibus, de acordo com os participantes da pesquisa.

Foi questionado também qual o tempo médio que os participantes da pesquisa gastam de sua residência até o seu local de estudo ou trabalho, e foi constatado que a maioria deles responderam que gastam acima de 30 minutos (34\%), seguido dos que responderam entre 20 a $30 \mathrm{~min}(33 \%)$ (Figura 14).

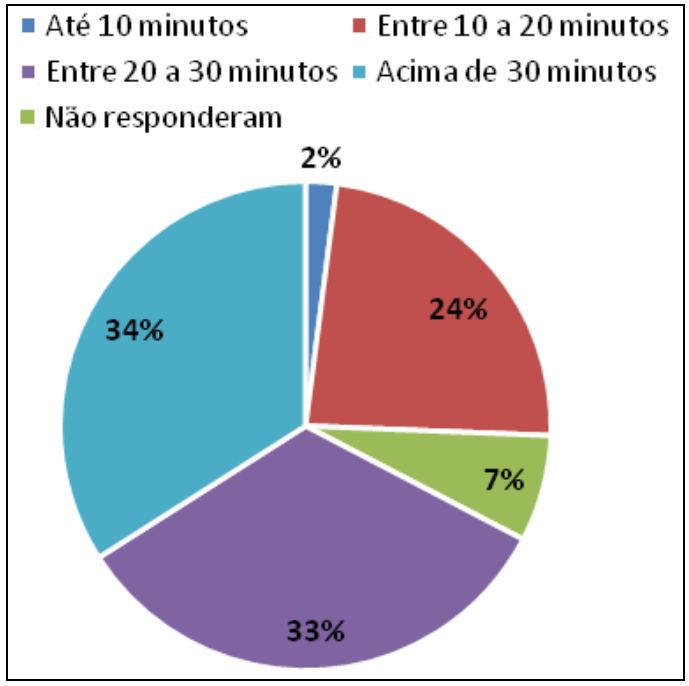

Figura 14. Tempo médio gasto da residência até o local de trabalho ou estudo, sob o ponto de vista dos participantes da pesquisa.

Em relação à qualidade física do transporte coletivo municipal, $31 \%$ dos participantes da pesquisa considera razoável, seguido de $25 \%$ que considera ruim (Figura 15).

Foi questionado também se os participantes da pesquisa utilizam bicicleta, em que $15 \%$ afirmaram que sim, $60 \%$ não utilizam esse meio de transporte, e $25 \%$ não responderam. Em relação à frequência com que utilizam a bicicleta, 34\% afirmam que fazem uso menos de três vezes por semana, 9\% utilizam mais de três vezes por semana, e 57\% não responderam.

Em relação à finalidade com que utilizam a bicicleta, $41 \%$ afirmam que utilizam para lazer, $27 \%$ para estudo, $15 \%$ para trabalho, e $17 \%$ para outras finalidades (Figura 16). 


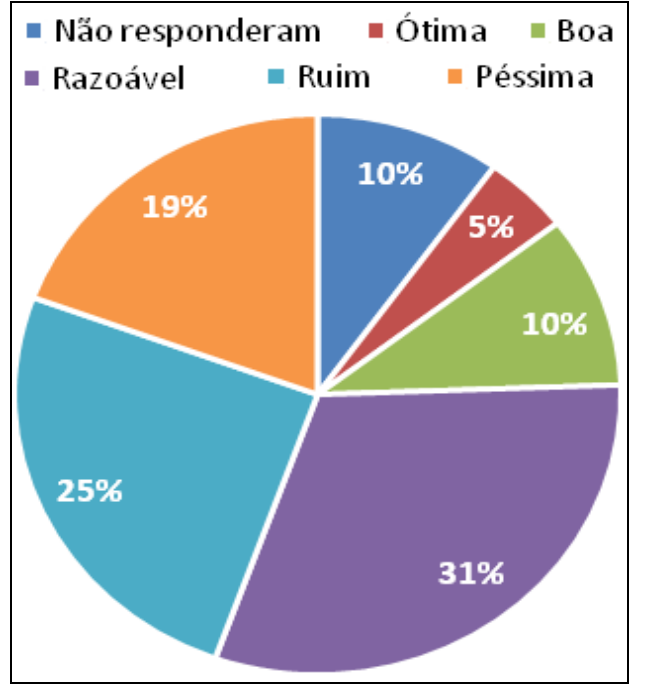

Figura 15. Condição física do transporte coletivo municipal na visão dos participantes.

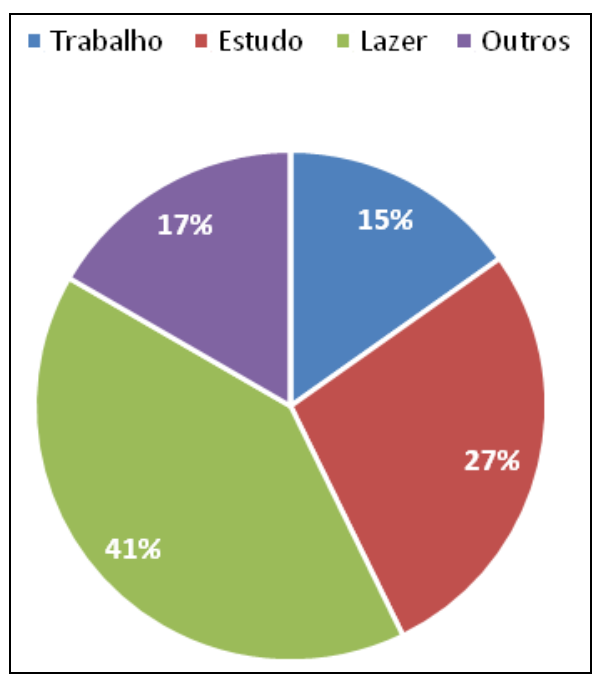

Figura 16. Finalidade para utilização da bicicleta, segundo os participantes da pesquisa.
Os participantes que afirmaram que não utilizam bicicleta, mencionaram que os principais problemas foram a má condição das vias (39\%), e distância de deslocamento (24\%) (Figura 17).

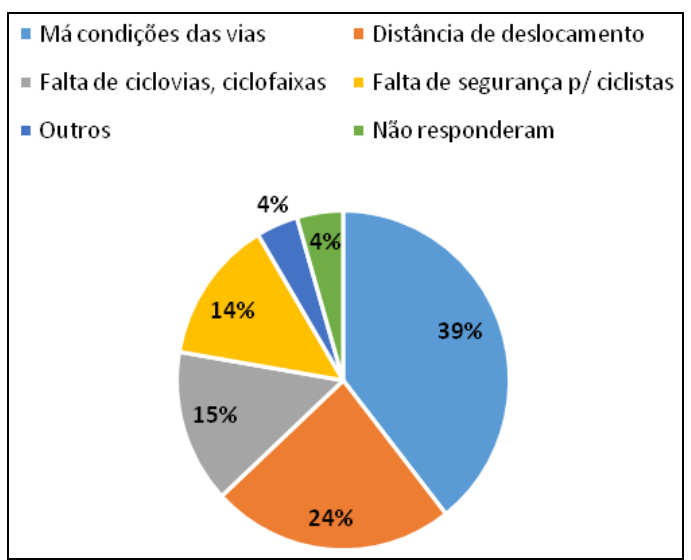

Figura 17. Motivo da não utilização da bicicleta na visão dos participantes da pesquisa.

Enquanto pedestre, as principais dificuldades encontradas durante $o$ passeio público são a má conservação das ruas (como buracos e desníveis, por exemplo) (31\%), seguido da má sinalização para os pedestres (20\%) (Figura 18).

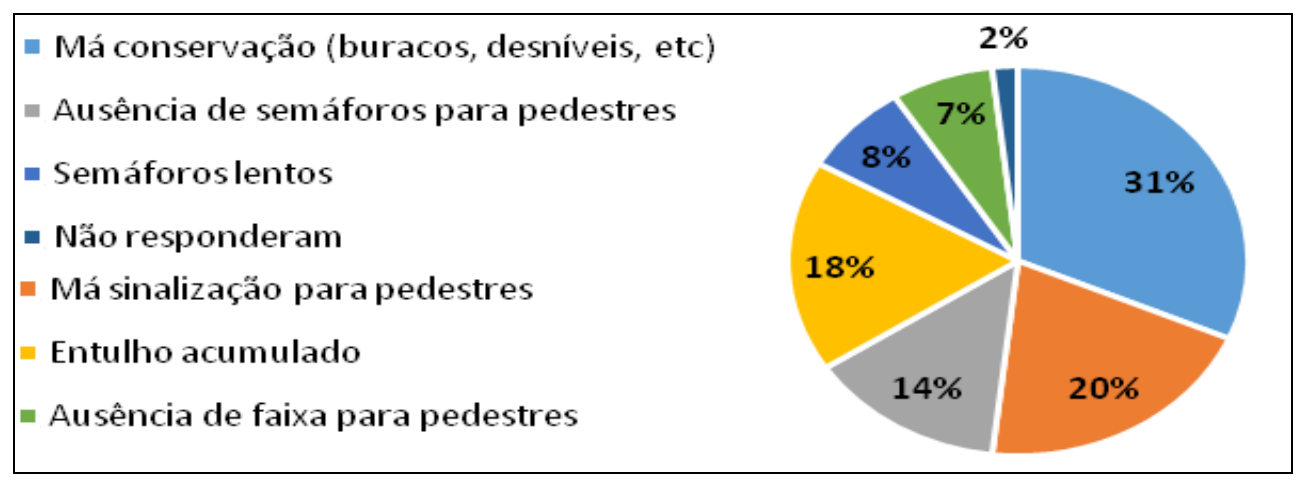

Figura 18. Principais dificuldades encontradas por parte dos pedestres no passeio público, de acordo com os participantes da pesquisa. 
Foi questionado quais os principais problemas de mobilidade/ acessibilidade do município de João Pessoa, então 19\% dos participantes da pesquisa mencionaram o excesso de veículos (trânsito movimentado), seguido $18 \%$ que consideraram a falta de ciclovias (Figura 19).
Foi perguntado aos participantes da pesquisa quais as principais ações para melhorar os problemas de mobilidade/acessibilidade no Município de João Pessoa, então 21\% mencionaram que é necessário ampliar a oferta de transporte coletivo, $20 \%$ consideraram a necessidade da ampliação de ciclovias e ciclofaixas (Figura 20).

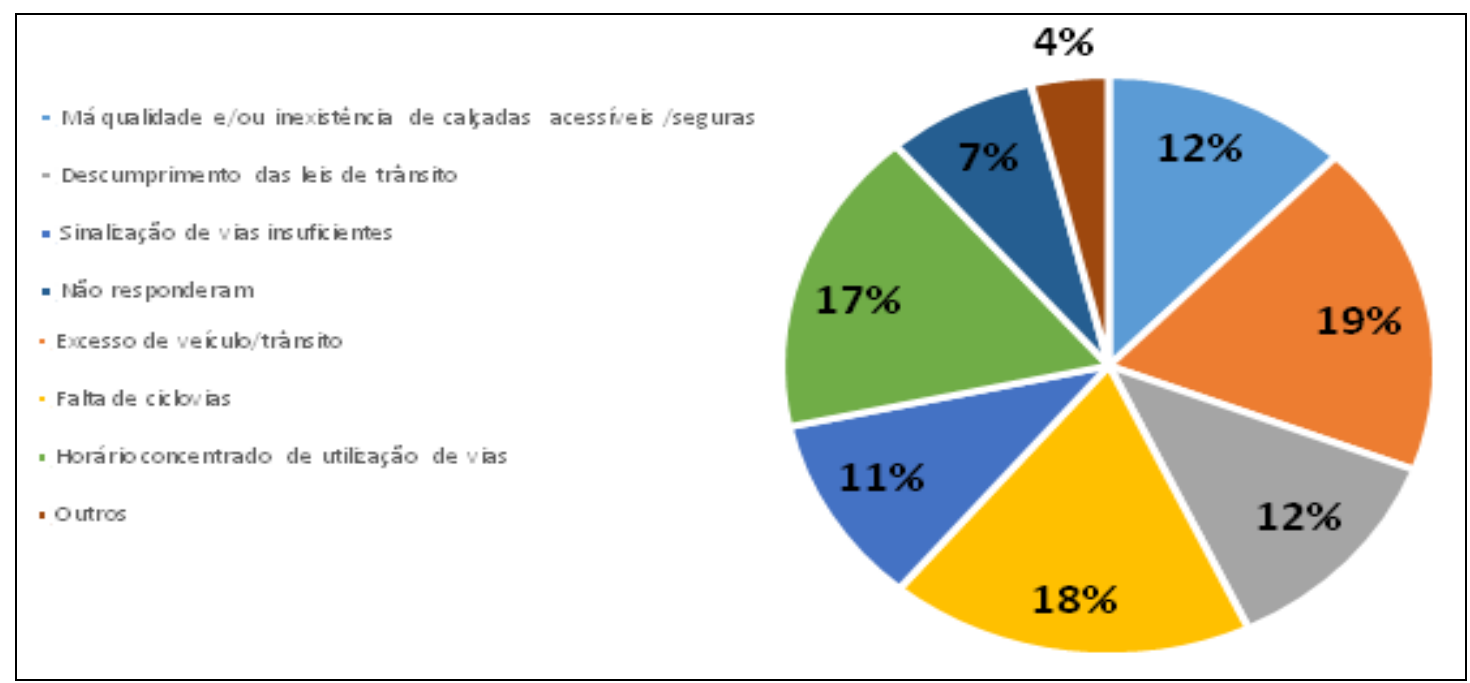

Figura 10. Principais problemas de mobilidade/acessibilidade do município de João Pessoa, sob o ponto de vista dos participantes da pesquisa.

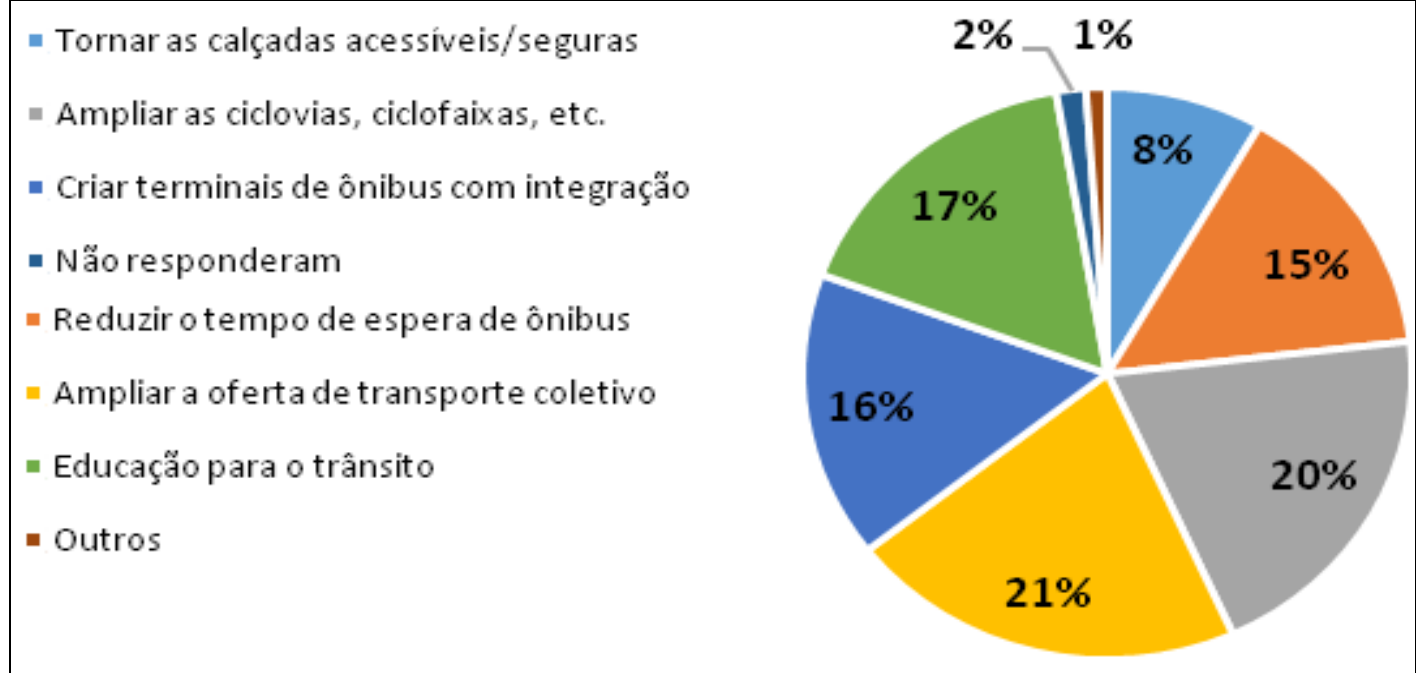

Figura 20. Principais ações para melhorar os problemas de mobilidade/acessibilidade no Município de João Pessoa, segundo os participantes da pesquisa. 
Em relação à avaliação dos terminais de integração municipais, 38\% consideraram razoável, enquanto que $20 \%$ considera bom (Figura 21).

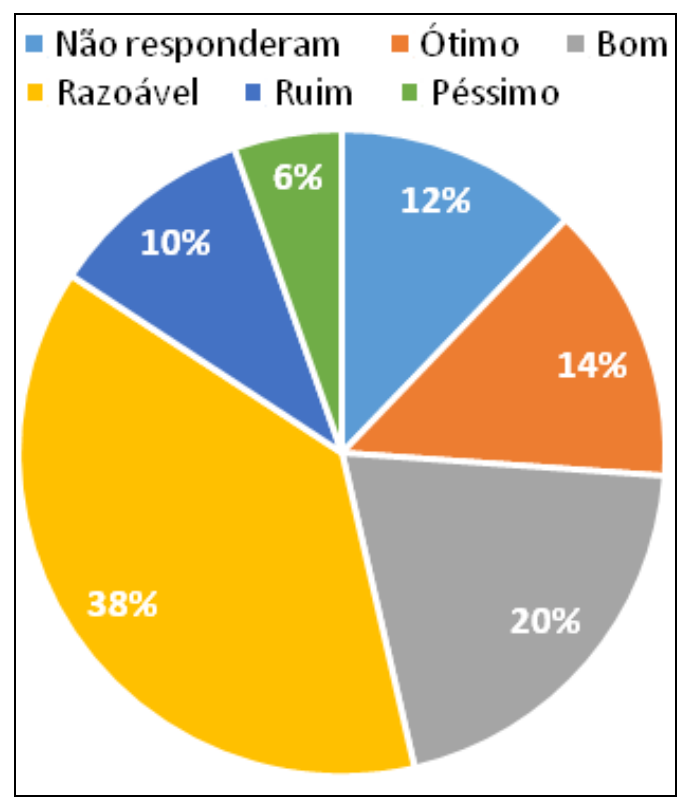

Figura 21. Avaliação dos terminais de integração municipais, na visão dos participantes.
A respeito do percentual de aumento do tempo de deslocamento nos últimos cinco anos, $35 \%$ dos participantes da pesquisa afirmaram que aumentou mais de $50 \%$, seguido de $25 \%$ que mencionaram que aumentou entre 20 a $50 \%$ (Figura 22).
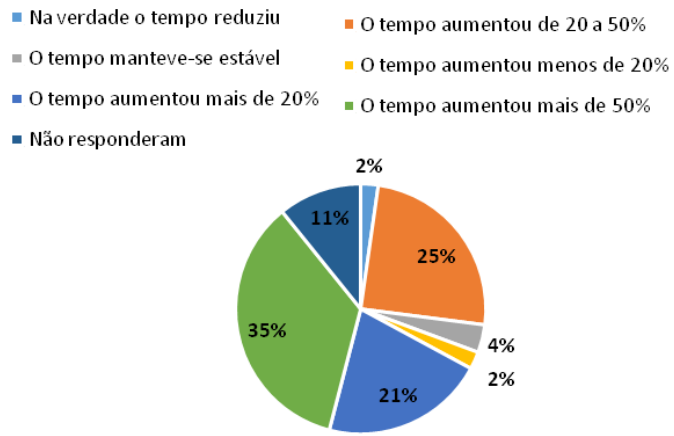

Figura 22. Percentual de aumento do tempo de deslocamento nos últimos cinco anos, de acordo com os participantes da pesquisa.

Em relação à escolaridade, $20 \%$ possuem Graduação Completo, seguido de $17 \%$ com Ensino Fundamental Completo (Figura 23).

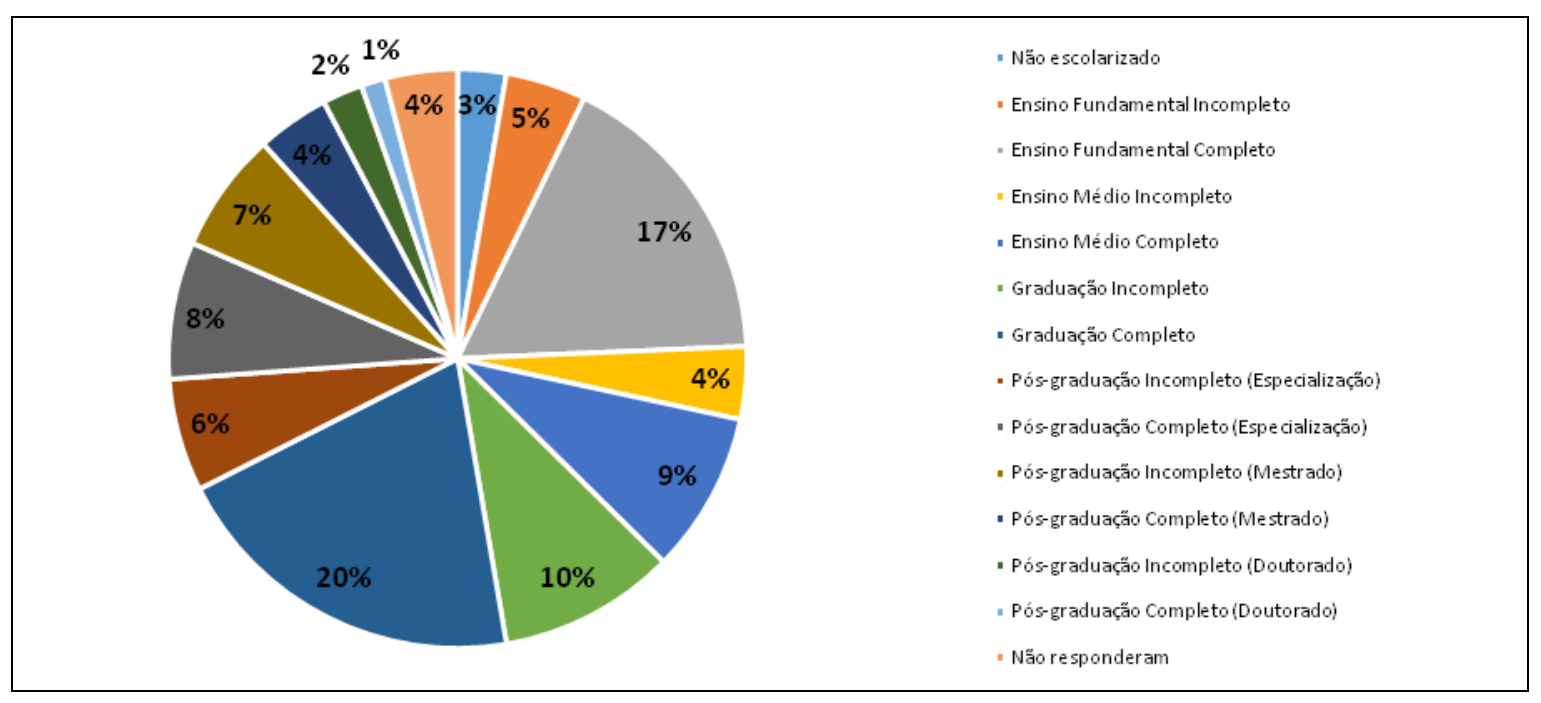

Figura 23. Nível de escolaridade dos participantes da pesquisa. 


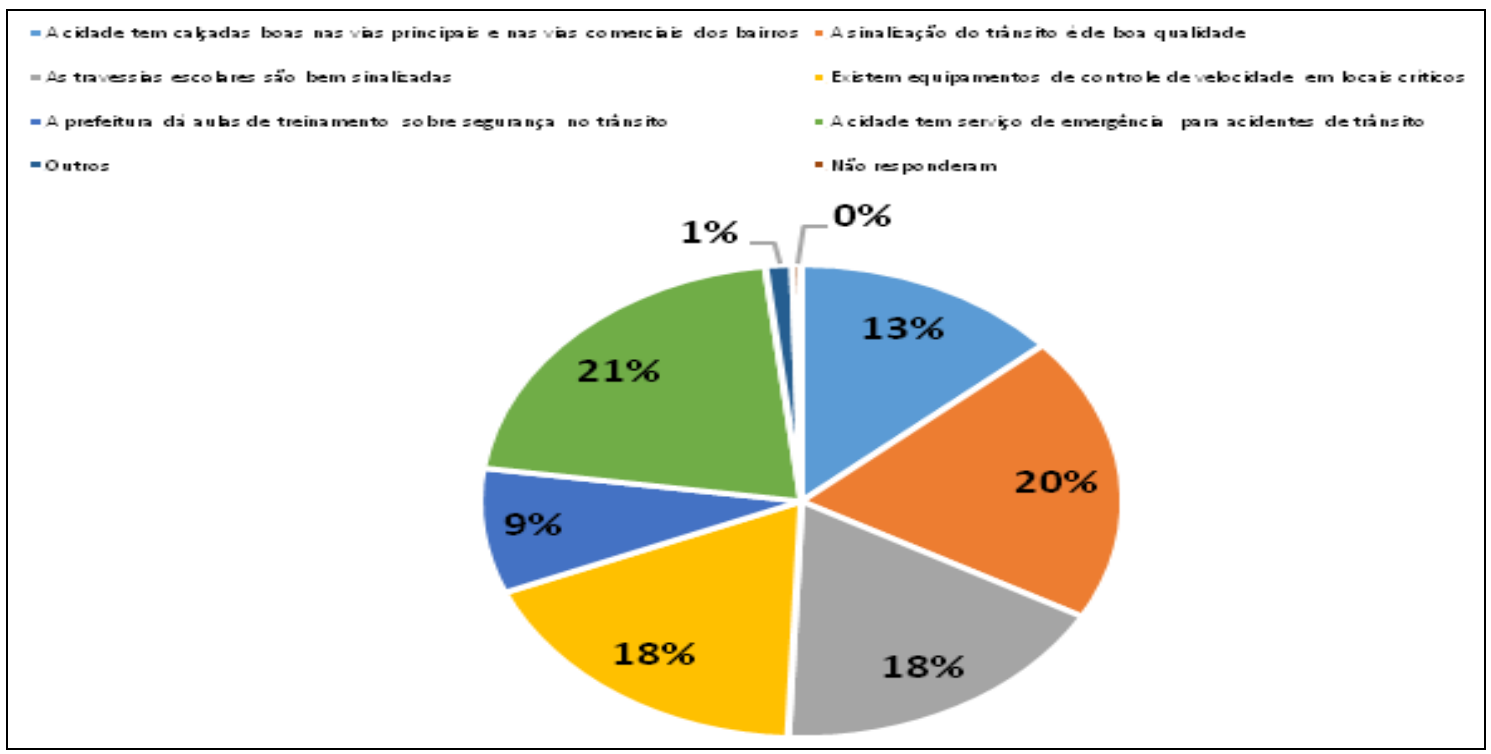

Figura 24. Percepção dos participantes acerca da segurança no trânsito no município de João Pessoa.

Em relação à percepção dos participantes sobre a segurança no trânsito, 21\% afirmaram que o Município de João Pessoa possui serviço de emergência para acidentes de trânsito, seguido de $20 \%$ que consideraram que a sinalização do trânsito é de boa qualidade (Figura 24).

Em relação à percepção a respeito da equidade na mobilidade/ acessibilidade no Município de João Pessoa, a maioria dos participantes da pesquisa afirmou que as pessoas que tem desconto ou gratuidade no transporte coletivo são respeitadas quando o utilizam (30\%), seguido de $27 \%$ que consideraram que as calçadas e cruzamentos estão adequados às necessidades dos idosos e portadores de deficiência (Figura 25).

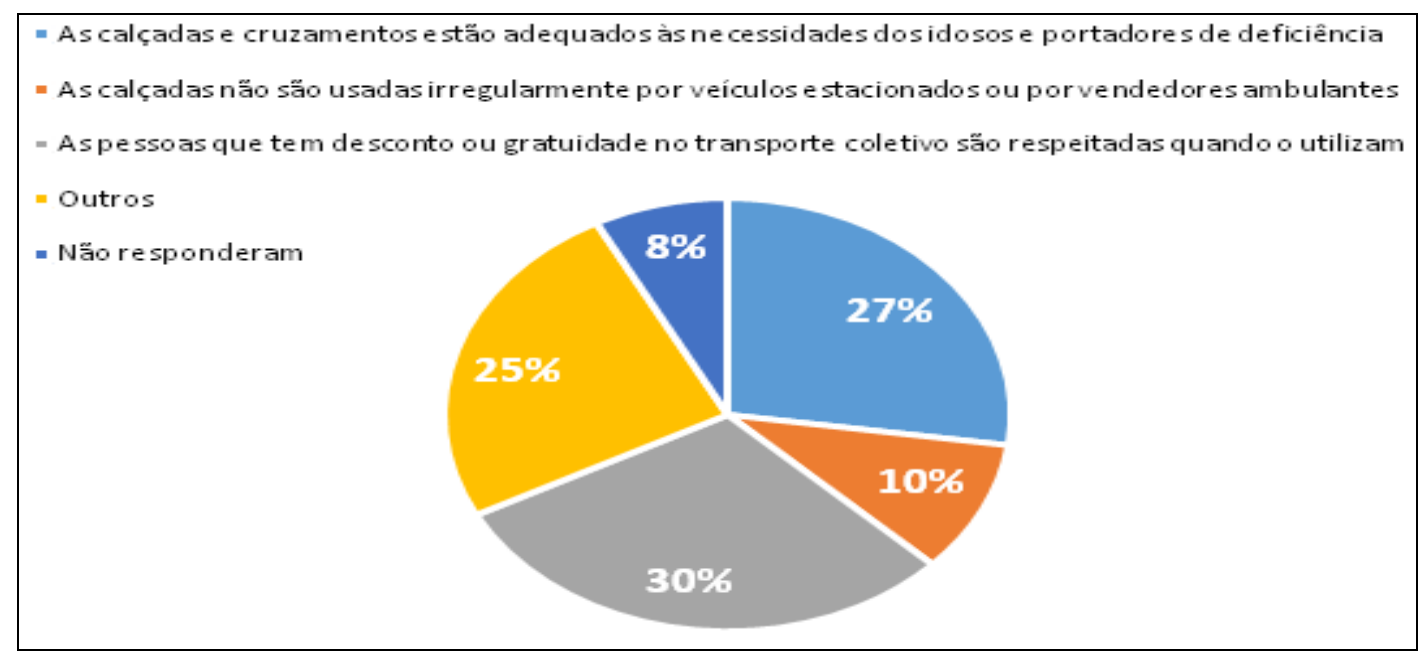

Figura 25. Percepção dos participantes a respeito da equidade na mobilidade/acessibilidade no Município de João Pessoa. 
Foi analisado também acerca da percepção dos participantes da pesquisa sobre a civilidade no trânsito, então 19\% mencionaram que as pessoas respeitam as filas nas entradas em outras vias, evitando formação de filas duplas ou triplas; seguido de $17 \%$ que consideraram que os motoristas deixam livres os cruzamentos (Figura 26).

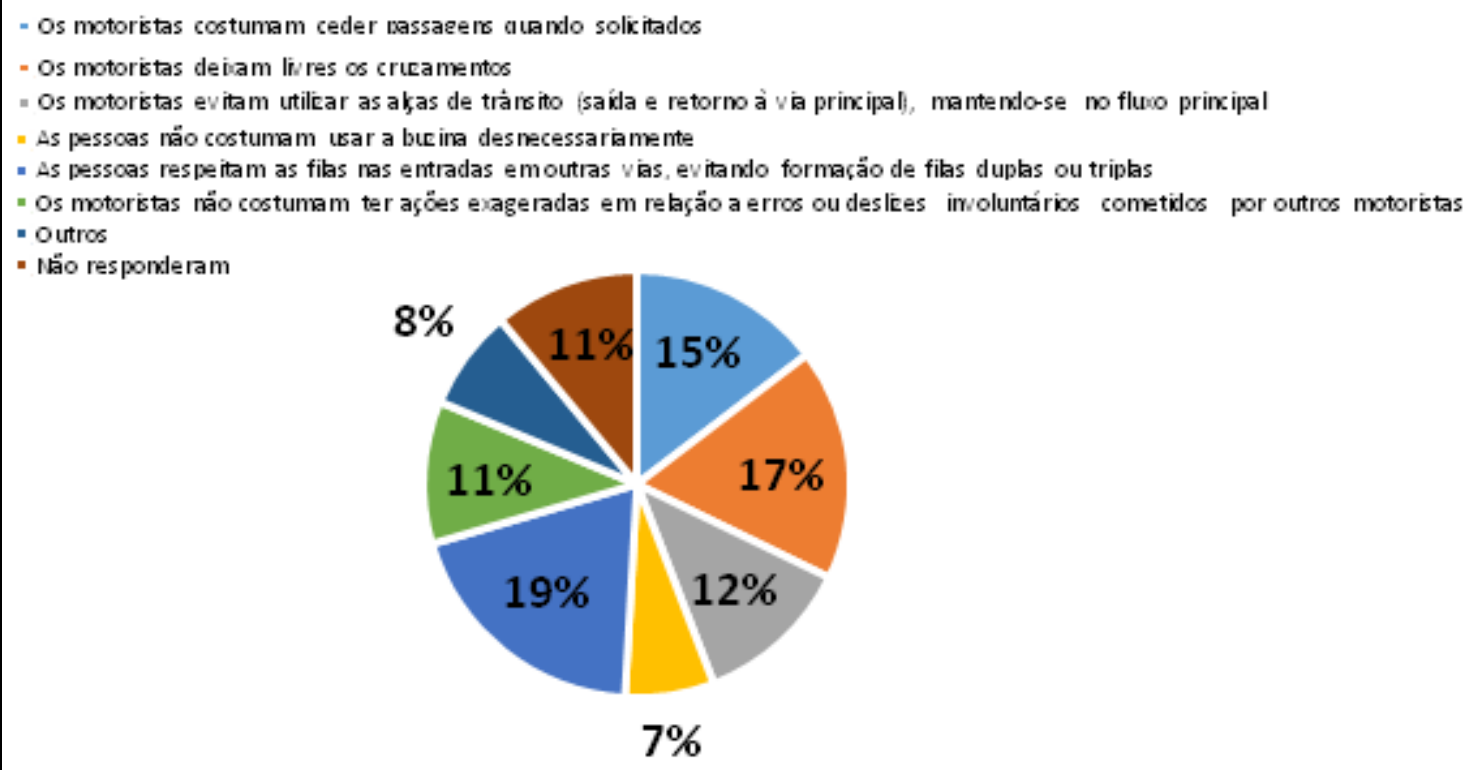

$7 \%$

Figura 26. Percepção dos participantes da pesquisa sobre a civilidade no trânsito no município de João Pessoa.

Foi questionado também qual a disposição da população estudada para contribuir com o sistema de trânsito do Município de João Pessoa, então 42\% dos participantes da pesquisa afirmaram que se disporiam a utilizar o transporte coletivo se o tempo de deslocamento fosse reduzido quando comparado ao transporte próprio; seguido de $33 \%$ que se disporiam a ir ao trabalho de bicicleta se a cidade tivesse um sistema abrangente de ciclovias (Figura 27).

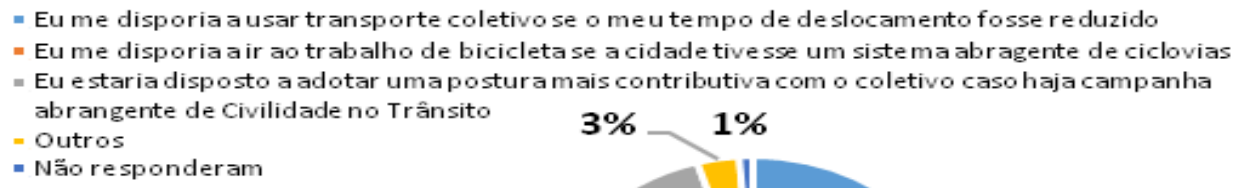

Figura 27. Disposição dos participantes da pesquisa em contribuir com o sistema de trânsito do Município de João Pessoa. 
Foi questionado aos participantes a respeito da atuação do órgão responsável dentro do sistema de trânsito, então $16 \%$ dos participantes da pesquisa mencionaram que a atuação do órgão responsável favorece um maior nível de civilidade, seguido de $15 \%$ que consideraram que tal órgão favorece o fluxo no trânsito (Figura 28).

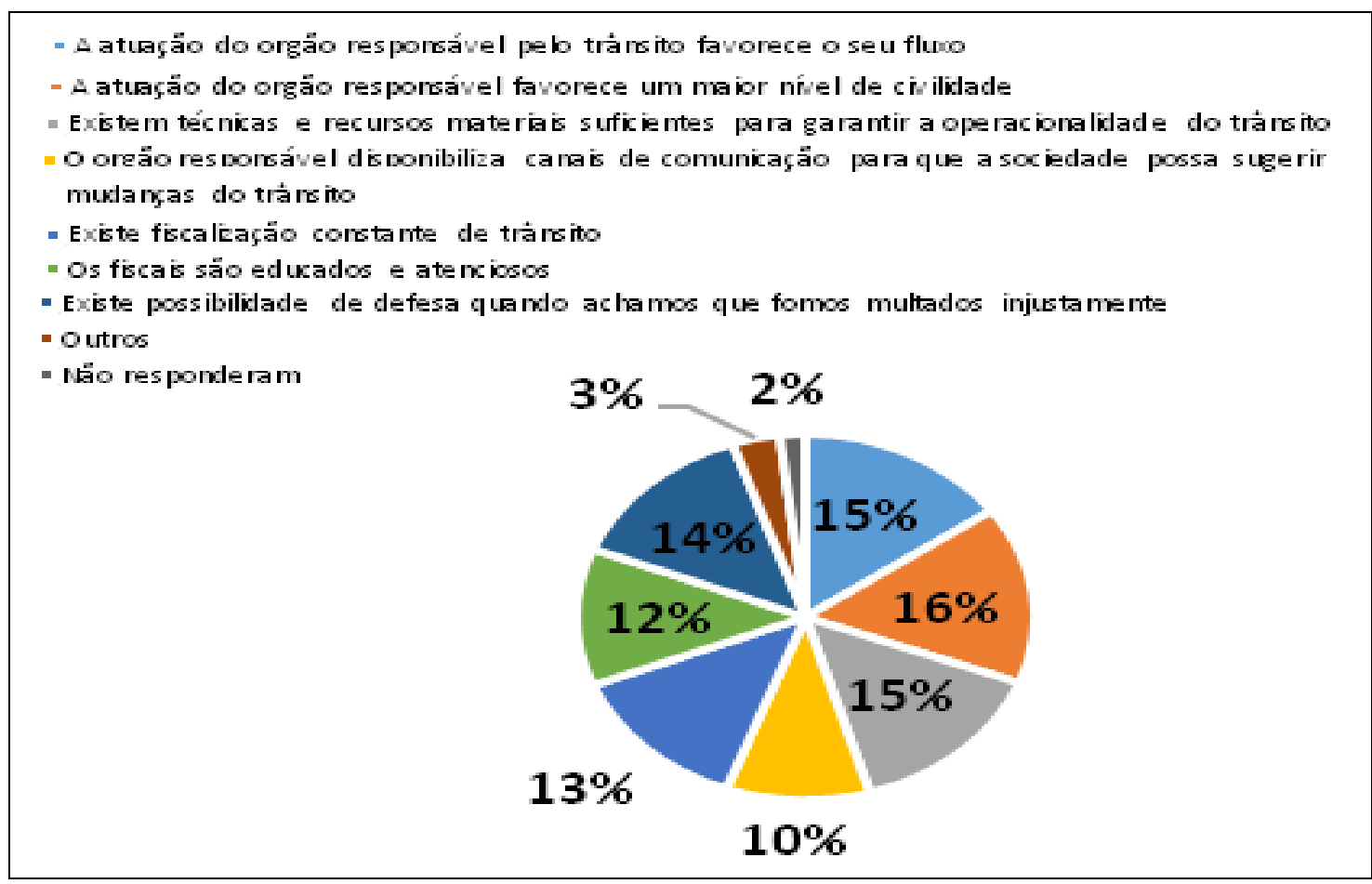

Figura 28. Atuação do órgão responsável pelo trânsito, sob o ponto de vista dos participantes da pesquisa.

\section{Áreas verdes}

Em seguida, está a análise das seis questões sobre "Áreas Verdes". A primeira refere-se ao que os participantes entendem sobre áreas verdes, e $29 \%$ destes responderam em uma visão ecológica, seguido de $25 \%$ em uma visão paisagística (Figura 29).

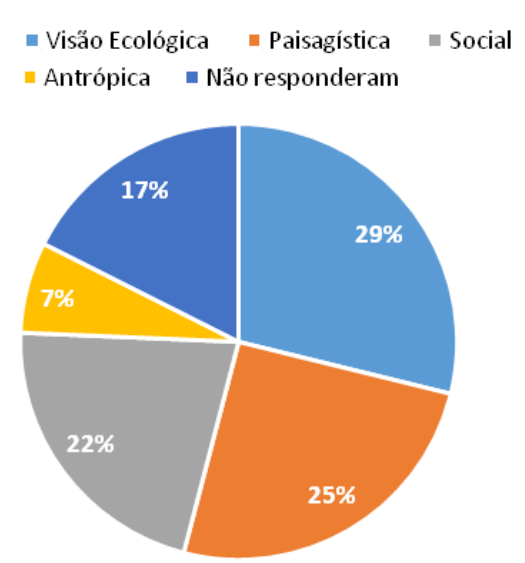

Figura 29. Visão a respeito do questionamento acerca do entendimento sobre áreas verdes, sob o ponto de vista dos participantes da pesquisa. 
A segunda questão perguntou se os participantes consideraram João Pessoa como uma cidade verde, então $58 \%$ afirmaram que sim, $29 \%$ afirmaram que não, e $13 \%$ não responderam. Nesta mesma pergunta, foi analisado o motivo que levou os participantes a responderem porque consideraram João Pessoa uma cidade verde, e $32 \%$ responderam em uma visão, seguido de $26 \%$ em uma visão paisagística (Figura 30).

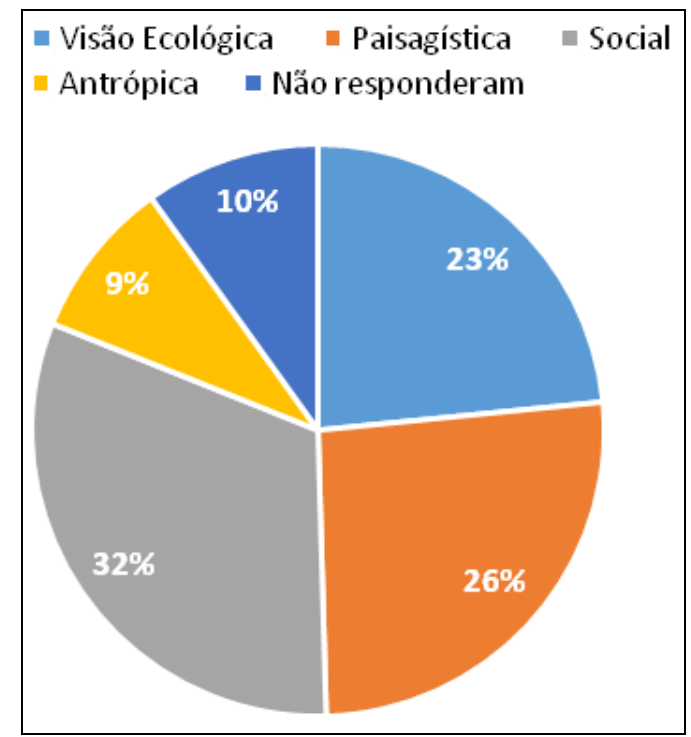

Figura 30. Visão acerca do motivo de João Pessoa ser considerada uma cidade verde, sob o ponto de vista dos participantes da pesquisa.

Em seguida, foi questionado a respeito do Parque Zoobotânico Arruda Câmara (conhecido como "Bica") e do Jardim Botânico Benjamim Maranhão (Figura 31). 71\% afirmaram que possuem uma visão positiva destes parques, enquanto 29\% afirmaram que não. $90 \%$ dos participantes da pesquisa mencionaram que costumam frequentálos, enquanto que $10 \%$ mencionaram que não frequentam. Em relação ao motivo porque frequentam, $45 \%$ mencionaram que visitam estes locais em uma visão paisagística, 35\% em uma visão social, e $20 \%$ em uma visão ecológica. Em relação à frequência com que visitam estes lugares, 53\% visitam algumas vezes ao ano, $42 \%$ algumas vezes ao mês, e $5 \%$ algumas vezes por semana.

A pergunta seguinte questionou se os participantes consideraram que as praças e a Cidade de João Pessoa estão bem arborizadas, então $62 \%$ dos participantes da pesquisa afirmaram que não, $26 \%$ afirmaram que sim, e $12 \%$ não responderam. Em relação ao motivo que levaram os participantes a responderem a este questionamento, 36\% responderam em uma visão antrópica, seguido de $29 \%$ que responderam em uma visão social (Figura 31).

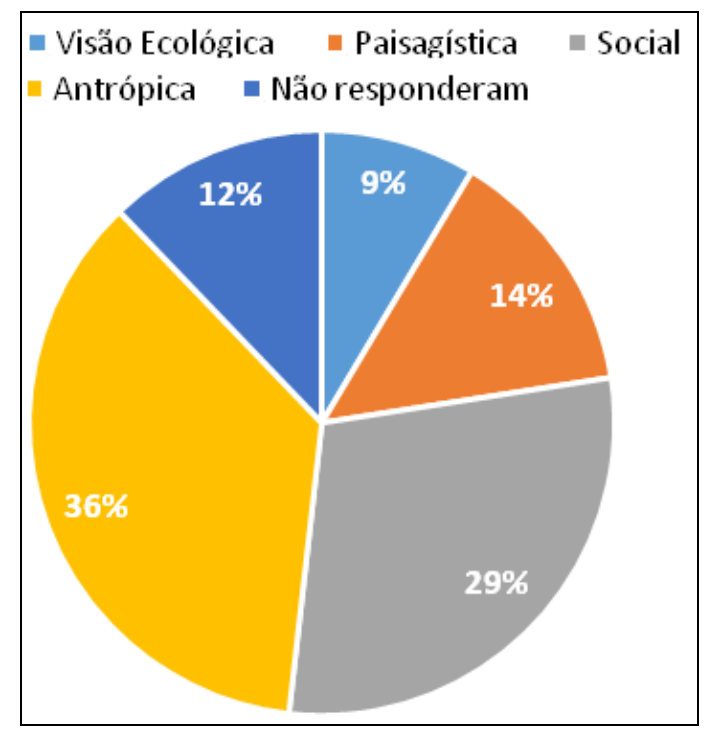

Figura 31. Visão dos participantes acerca de considerar as praças e a cidade de João Pessoa como bem arborizadas.

A quinta pergunta sobre áreas verdes, questionou qual a importância das árvores e áreas verdes em uma cidade, então $36 \%$ responderam sob o ponto de vista social, seguido de $20 \%$ que responderam em uma visão ecológica (Figura 32). 


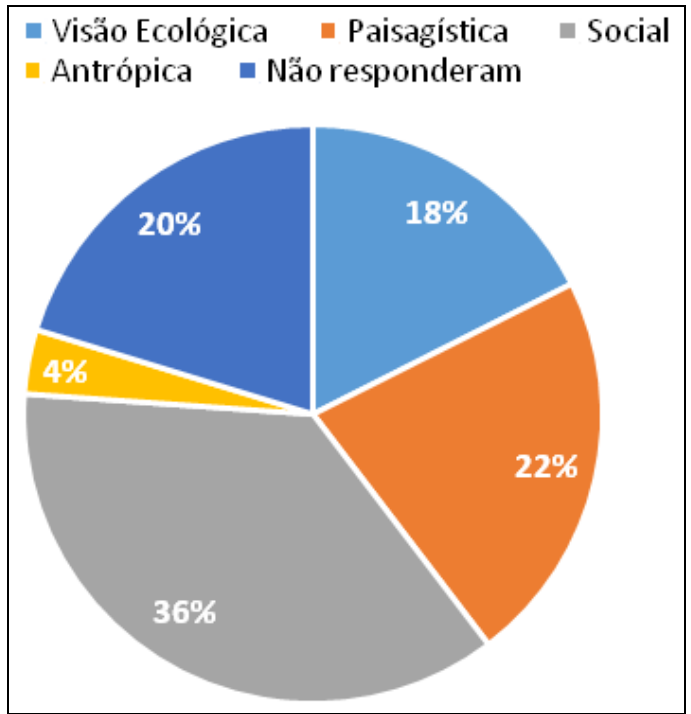

Figura 32. Visão dos participantes da pesquisa acerca da importância das árvores e áreas verdes em uma cidade.

Também foi questionado qual a importância do meio ambiente para uma cidade, então $36 \%$ responderam sob o ponto de vista social, seguido de $28 \%$ que responderam sob uma visão paisagística (Figura 33).

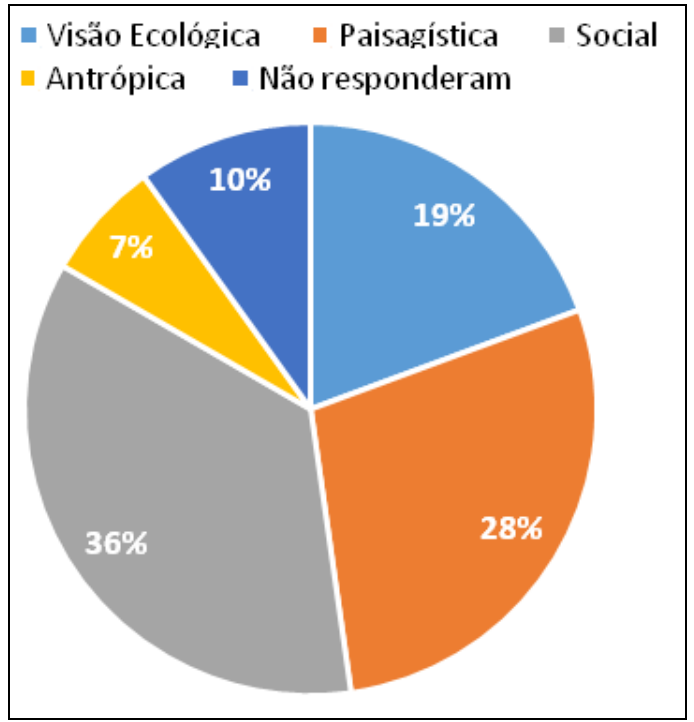

Figura 33. Visão dos participantes da pesquisa sobre a importância do meio ambiente para uma cidade.
Finalmente, foi questionado se os participantes achavam que João Pessoa está preparada para receber o título de Cidade Sustentável, então $56 \%$ acham que sim, 26\% acham que não, e 18\% não responderam (Figura 34). E o motivo para que os que acham que sim, $66 \%$ responderam em uma visão social, e 34\% responderam em uma visão antrópica (Figura 35).

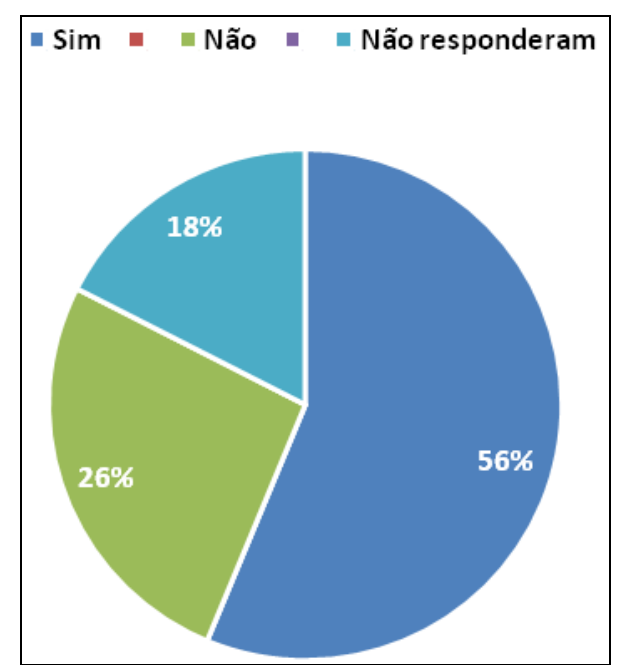

Figura 34. Quantitativo dos participantes a respeito se consideram João Pessoa como preparada para receber o título de Cidade Sustentável.

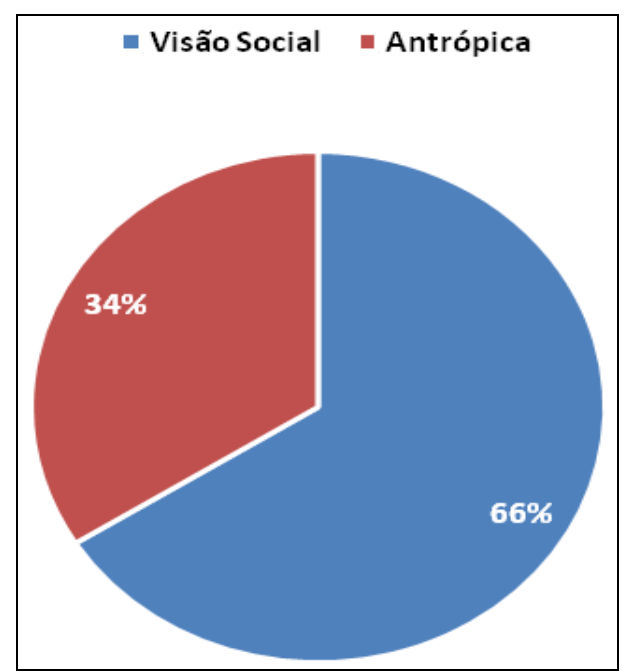

Figura 35. Percepção dos entrevistados a respeito do motivo que consideram João Pessoa como Cidade Sustentável. 


\section{Discussão}

O Município de João Pessoa foi fundado em 1585, batizado de "Cidade Real de Nossa Senhora das Neves", sendo a terceira capital de estado mais antiga do Brasil. Deste modo, não foi planejada como uma cidade sustentável, que pudesse dar oportunidade a todos os cidadãos se apropriassem de seus espaços, mas ela foi se moldando de acordo com a necessidade de cada época.

Criada dentro de uma área verde, o principal desafio dos colonizadores de João Pessoa foi desbravar a Mata Atlântica para a instalação da metrópole, que cresceu do centro, nas imediações do Rio Sanhauá, para as Praias de Cabo Branco e Tambaú no início, prosseguindo para a zona sul da cidade, hoje os bairros Castelo Branco, Bancários, Mangabeira, Mangabeira, Valentina e Ernesto Geisel, concomitante com a ocupação da região litoral, Manaíra e Bessa, ao Norte, e Altiplano Cabo Branco, ao sul (Castro et al., 2015).

A gênese da Cidade de João Pessoa começou com um conflito com a natureza, onde a supressão da vegetação foi empregada para dar lugar aos equipamentos urbanos.

Considerando que o Município de João Pessoa não nasceu planejado para ser uma cidade sustentável, o estudo atual da mobilidade urbana e das áreas verdes, bem como a percepção dos moradores com relação a estas áreas é extremamente importante para auxiliar na avaliação das políticas públicas implantadas.

0 estudo que enfoquem a percepção da população em relação ao meio ambiente é bastante útil para um melhor planejamento e compreensão do ambiente urbano, considerando que o uso cotidiano dos espaços, dos equipamentos e serviços urbanos, faz com que a população sinta diretamente o impacto da qualidade ambiental (Rio e Oliveira, 1999).

Para Trigueiro (2003) a percepção ambiental é uma tomada de consciência do ambiente pelo homem, ou seja, é perceber o ambiente onde está localizado e inserido, aprendendo a proteger e cuidar da melhor forma possível. Entretanto, Lacerda et al. (2010) acreditam que esta percepção apenas poderá ser compreendida por intermédio do conhecimento, do entendimento, da integração e, sobretudo, do respeito à natureza que o rodeia.

No dizer de Melazo (2005):

[...] o estudo da percepção ambiental se torna fundamental para que se possa compreender melhor as interrelações entre o homem e o ambiente no qual vive, suas expectativas, satisfações e insatisfações, valores e condutas, como cada indivíduo percebe, reage e responde diferentemente frente às ações sobre o meio. 0 estudo deve buscar não apenas o entendimento do que o indivíduo percebe, mas também promover a sensibilização, a consciência, bem como o desenvolvimento do sistema de compreensão do ambiente ao seu redor. (Melazo, 2005: 46-47).

Assim, o estudo da percepção ambiental pode ser um importante instrumento para avaliar o andamento da implementação de políticas públicas, inclusive relacionadas à mobilidade urbana e às áreas verdes.

\section{Mobilidade urbana}

A estrutura de circulação do Município de João Pessoa dá-se principalmente por meio de ônibus, entretanto, certamente devido à facilidade de acesso aos meios de financiamento (Bohusch e Scheibe, 2014), o uso de automóveis individuais tem aumentado de modo que a cidade tem que se adaptar, para adequar às novas realidades de deslocamentos.

De acordo com o que estabelece no art. 30, da Constituição Federal de 1988 (Brasil, 1988) cabe aos municípios 
a realização projetos de infraestrutura urbano sustentável.

O Município de João Pessoa vem se esforçando para cumprir os ditames constitucionais, ao fazer com que a mobilidade urbana na cidade seja a mais eficiente. Para conseguir alcançar seus objetivos, foram feitas intervenções em vários setores da cidade, por exemplo, além de melhorar 0 capeamento asfáltico, a edilidade alargou e instalou ciclovia na Avenida José Américo de Almeida (Beira Rio), melhorando a capacidade de circulação de veículos, pedestres e ciclistas.

Além disto, na Avenida Dom Pedro II, houve uma melhoria na via, através do capeamento asfáltico, bem como foi reservada uma faixa exclusiva para a circulação de veículos públicos, com o intuito de diminuir o tempo das viagens dos usuários do centro para os bairros e vice e versa.

Embora sejam notórios os esforços envidados pela edilidade para facilitar a mobilidade urbana no Município de João Pessoa, ao serem questionados, a maioria dos respondentes informaram que o excesso de veículos é a maior dificuldade para os deslocamentos nas vias. Sendo que aliados à utilização de bicicleta apenas para o lazer, faz de João Pessoa uma cidade que utiliza o modelo automobilístico-rodoviário urbano para a mobilidade da população.

Passos et al. (2012), alertam para a necessidade urgente de se procurar alternativas para neutralizar ou minimizar o impacto dos problemas urbanos de João Pessoa, decorrentes, ainda segundo os autores, da adoção do modelo automobilístico-rodoviário urbano, que vem provocando, de acordo com Barczak e Duarte (2012), elevados custos sociais, econômicos e ambientais.

No tocante à adequação das ruas e avenidas para acolhimentos das pessoas com deficiência e mobilidade reduzida, várias estruturas foram instaladas de modo a facilitar os deslocamentos destas pessoas. Por exemplo, foram instalados 45 pontos de rebaixamento para cadeirantes na Avenida Epitácio Pessoa, 13 na Avenida Ruy Carneiro, e 51 na Avenida José Américo de Almeida (Beira Rio). Além disto, a Secretaria de Mobilidade Urbana do Município de João Pessoa (SEMOB) distribui gratuitamente credenciais que permitem que estes cidadãos possam estacionar seus veículos em vagas reservadas para este fim, tanto em espaços públicos, quanto nos privados de acesso público, como shoppings, supermercados e similares.

Ao serem questionados, os respondentes informaram que a má conservação das ruas (como buracos e desníveis, por exemplo) e a maior dificuldade encontrada em sua mobilidade. Tal resultado também foi constatado por Pizzol e Ribeiro (2005), ao analisarem a mobilidade nos passeios urbanos no Município de João Pessoa, que reconheceram que estes espaços não ofereciam segurança para o tráfego das pessoas, pugnando pela necessidade da edilidade implantar políticas públicas que permitam o uso e a acessibilidade destes espaços coletivos, contribuindo para a apropriação da cidade por todos os cidadãos.

Os respondentes também mencionaram que as principais ações necessárias para melhorar os problemas de mobilidade/acessibilidade no Município de João Pessoa seriam ampliar a oferta de transporte coletivos e ampliar as ciclovias e ciclofaixas e também informaram que estariam disposto a utilizar o transporte coletivo de passageiros, caso o tempo de deslocamento fosse reduzido.

\section{Áreas verdes}

O Município de João Pessoa é conhecido como a segunda cidade mais verde do mundo, perdendo apenas para a cidade de Paris, a capital da França, e sua arborização pode ser encontrada em áreas verdes públicas e privadas, bem como acompanhando o sistema viário nos diversos bairros. 
A Mata do Buraquinho, onde está instalado o Jardim Botânico, e o Parque Zoobotânico Arruda Câmara (Bica) são as principais áreas verdes da Cidade de João Pessoa, frequentados por uma grande parcela da população.

A Lagoa do Parque Solon de Lucena, que foi recentemente revitalizada, e a Praça da Independência são outros espaços verdes públicos que conseguem atrair os pessoenses para o seu lazer semanal.

Além de melhorar a qualidade de vida nas cidades e a saúde física e mental da população (Ribeiro, 2009), melhorar o microclima local e o equilíbrio edáfico, reduzir a velocidade dos ventos, da poluição, inclusive a sonora, bem como contribuir para a manutenção da avifauna (Lima Neto et al., 2010; Souza et al., 2016; Martelli e Delbim, 2017; Novais et al., 2017), executa um papel notável na estética da cidade, embelezando as vias públicas (Andrade e Jeronimo, 2015), as áreas verdes urbanas tem a importante função de reconectar o homem urbano ao ambiente natural. É a partir das vivências nestas áreas que o homem moderno se reconcilia com a natureza, sendo este, portanto, um agente de bemestar social.

Embora, de acordo com Lucena et al. (2011), considerando as áreas de matas e as reservas reconhecidas do território do Município de João Pessoa, o seu índice foi de pouco mais de $8 \%$ de mata em seu território, a maioria dos respondentes reconheceram que consideram a Cidade de João Pessoa como uma cidade verde, apresentando visão positiva sobre o Parque Solon de Lucena e o Jardim Botânico Benjamim Maranhão. Entretanto, a maioria dos respondentes não a considera bem arborizada, no entanto a maioria informa que a cidade está preparada para receber o título de cidade sustentável, mostrando uma certa dubiedade nas respostas.

Vale ressaltar entretanto que, ao analisarem a sustentabilidade do Município de João Pessoa aplicando o barômetro da sustentabilidade, Lucena et al. (2011), constataram que a cidade apresentava, àquela época, um grau de sustentabilidade intermediário, mas ao analisar as dimensões do meio ambiente, encontrou um grau potencialmente sustentável, demonstrando que os esforços da edilidade estão surtindo efeito na condução do município para a sustentabilidade.

Observa-se assim que o Município de João Pessoa está conduzindo projetos eficientes na mobilidade urbana e nas áreas verdes, transformando-a numa cidade sustentável.

\section{Considerações Finais}

O Município de João Pessoa foi fundado ainda em 1585, pelos colonizadores portugueses, sendo a terceira capital de estado mais antiga do Brasil, não sendo caracterizado nem planejado na sua fundação como uma cidade sustentável, que pudesse dar oportunidade a todos os cidadãos a se apropriarem de seus espaços constituintes. 0 município foi se moldando às necessidades de cada época.

Criado dentro de uma área verde às margens do Rio Sanhauá, o Município de João Pessoa foi se expandindo primeiramente desbravando-se a Mata Atlântica original para a instalação da metrópole, que cresceu do Centro para as Praias de Cabo Branco e Tambaú no início, seguindo em direção à zona sul, onde foram instalados os Bairros do Castelo Branco, Bancários, Mangabeira, Valentina de Figueiredo e Ernesto Geisel, concomitante com a ocupação da região litoral, Manaíra e Bessa, ao norte, e Altiplano Cabo Branco, ao sul (Castro et al., 2015).

A estrutura de circulação do Município de João Pessoa ainda continua dando-se principalmente por meio de ônibus, entretanto nestes últimos anos houve um aumento significativo na quantidade de automóveis e motocicletas nas vias urbanas da cidade, certamente devido à facilidade de crédito ao 
consumidor, caracterizando o município como aquele que adota o modelo automobilístico-rodoviário urbano para a mobilidade da população.

Embora o Município de João Pessoa venha realizando projetos de infraestrutura urbano sustentável, com intervenções em vários setores da cidade, que incluem capeamento asfáltico, alargamento de vias, instalação de ciclovias, rebaixamento de calçadas, faixas exclusivas para ônibus, devido à malha urbana ser estruturada em vias originalmente estreitas, que foram mantidas durante $o$ decorrer das intervenções, a maioria dos respondentes desta pesquisa informou que o excesso de veículos é a maior dificuldade para os deslocamentos nas vias. Entretanto, as vias públicas estreitas também contribuem para dificultar o deslocamento dos veículos.

Em consequência dos excessos de veículos e das vias estreitas da Cidade de João Pessoa, a maioria dos respondentes da pesquisa informou que a má qualidade dos ônibus e o tempo de espera superior a 30 minutos desestimulam o uso deste tipo de transporte. Tal comportamento provoca a utilização de veículos monousuários, aumentando ainda mais o fluxo de veículos nas vias públicas e consequentemente aumenta o tempo de espera dos passageiros nos pontos de transportes públicos, devendo o poder público intervir para que sejam oferecidos transporte públicos de qualidade e confortáveis.

Se não bastasse o Município de João Pessoa apresentar as vias públicas estreitas, a maioria dos respondentes informaram que a má conservação das calçadas (como buracos e desníveis, por exemplo) é a maior dificuldade encontrada em sua mobilidade. Neste ponto, é dever do poder público notificar os moradores para conservarem as suas calçadas, de modo que seja possível a mobilidade universal de todos os transeuntes, principalmente os portadores de deficiência, como os usuários de cadeiras de roda e cegos, além da população mais idosa.

Parece que o título outorgado pela Assembleia Legislativa da Paraíba à João Pessoa de Cidade Verde (Paraíba, 1999) é bem visto pela população, tendo em vista que maioria dos respondentes da pesquisa não só reconhecem que o Município de João Pessoa é uma cidade verde, como está preparado para receber o título de cidade sustentável. Certamente, a Mata do Buraquinho, o Parque Zoobotânico Arruda Câmara (Bica), a Praça da Independência e a Lagoa do Parque Solon de Lucena, são as principais áreas verdes da Cidade de João Pessoa que dão a percepção da quantidade florestas existentes na cidade.

Embora haja um boato de que a Cidade de João Pessoa seria a segunda cidade mais verde do mundo, perdendo apenas para Paris, na França, ainda está muito longe para que o município realizar esta façanha, tendo em vista que para o cálculo deste índice não entra no cômputo as áreas verdes públicas. Desde modo, pode-se dizer sem nenhum medo de errar que há um déficit no número de árvores nas áreas particulares. Não por menos, a maioria dos respondentes não considerou que a Cidade de João Pessoa seja bem arborizada. Entretanto, paradoxalmente, a maioria dos respondentes informou que a cidade está preparada para receber o título de cidade sustentável.

O Banco Interamericano de Desenvolvimento (BID), a Caixa Econômica Federal (CEF) e o Município de João Pessoa fizeram parceria para a expansão do Programa Iniciativa de Cidades Emergentes e Sustentáveis (ICES) no Brasil, para que possam ser realizados projetos de infraestrutura urbano sustentáveis, através de investimentos significativos nas áreas de mobilidade, meio ambiente, habitação, lazer e cultura, com a implantação do "Programa de Desenvolvimento Urbano Integrado e Sustentável no Município de João Pessoa", estruturado em três 
componentes (I) Desenvolvimento Urbano Sustentável e Gestão da Cidade, (II) Desenvolvimento Econômico e Competitividade, e (III) Fortalecimento Institucional e Gestão Pública, sendo prevista operação de crédito totalizando US\$200.000.000,00 (duzentos milhões de dólares), sendo US $\$ 100.000 .000,00$ (cem milhões de dólares) do BID e US\$100.000.000,00 (cem milhões de dólares) como contrapartida financeira (Oliveira-e-Silva, 2016-2017).

Desde modo, o Município de João Pessoa está conduzindo projetos do "Plano João Pessoa Sustentável", que envolvem de mobilidade urbana e nas áreas verdes, que poderão transformá-la numa cidade sustentável, diminuindo as desigualdades sociais que ainda existem na cidade.

\section{Material suplementar}

As tabelas referentes ao estudo estão disponíveis em: https://doi.org/ $10.21438 /$ rbgas.050927s.

\section{Declaração de conflito de interesses}

Os autores declaram não haver conflito de interesses.

\section{Referências}

ABNT - Associação Brasileira de Normas Técnicas. ABNT NBR ISO 37.120:2017 Desenvolvimento sustentável de comunidades - Indicadores para serviços urbanos e qualidade de vida. Rio de Janeiro: ABNT, 2017.

Alvares, C. A.; Stape, J L.; Sentelhas, P. C.; Gonçalves, J. L. M.; Sparovek, G. Köppen's climate classification map for Brazil. Meteorologische Zeitschrift, v. 22, n. 6, p. 711-728, 2014. https://doi.org/10.1127/ 0941-2948/2013/0507

Andrade, M. N. M. M.; Jeronimo, C. E. M. Diagnóstico da arborização do espaço urbano da Cidade de João Pessoa, PB. Revista Eletrônica em Gestão, Educação e Tecnologia Ambiental, v. 19, n. 3, p.194-208, 2015. Disponível em: <https://periodicos.ufsm.br/reget/article/vi ewFile/17785/pdf>. Acesso em: 14 nov. 2017.

Bargos, D. C.; Matias, L. F. Áreas verdes urbanas: um estudo de revisão e proposta conceitual. Revista Brasileira de Arborização Urbana, v. 6, n. 3, p. 172-188, 2011. Disponível em: <http://www.ige. unicamp.br/geoget/acervo/artigos/areas verdes urbanas Danubia.pdf $>$. Acesso em: 14 nov. 2017.

Barczak, R.; Duarte, F. Impactos ambientais da mobilidade urbana: cinco categorias de medidas mitigadoras. urbe, Revista Brasileira de Gestão Urbana, v. 4, n. 1, p. 13-32, 2012. https://doi.org/ 10.1590/S2175-33692012000100002

Bettencourt, L. M. A. Cidades como sistemas complexos. In: Furtado, B. A.; Sakowski, P.A. M.; TÓVOLli, M. H. Modelagem de sistemas complexos para políticas públicas. Brasília: IPEA, 2015. p. 241-263. Disponível em: <http://www.ipea.gov.br/ portal/images/stories/PDFs/150727_livro_ modelagem_sistemas.pdf $>$. Acesso em: 14 abr. 2017.

Boareto, R. A política de mobilidade urbana e a construção de cidades sustentáveis. Ciência \& Ambiente, n. 37, p. 73-92, 2008. Disponível em: <www.repositorio.unb.br/ bitstream/10482/11232/1/2011_GeovanyJe sseAlexandredaSilva.pdf $>$. Acesso em: 14 abr. 2017.

Bohusch, G.; Scheibe, L. F. Mobilidade urbana sustentável: um ensaio sobre o conceito. Geosul, v. 29, n. 57, p. 157-176, 2014. Disponível em: <https://periodicos.ufsc.br/ index.php/geosul/article/view/2177-

5230.2014v29n57p157/27890>. Acesso em: 14 nov. 2017.

Bonametti, J. H. Arborização urbana. Terra e Cultura, v. 19, n. 36, p.51-55, 2003. Disponível em: <http://web.unifil.br/docs/ revista_eletronica/terra_cultura/36/Terra e Cultura_36-6.pdf>. Acesso: 14 nov. 2017.

Brasil. Constituição da República Federativa do Brasil de 1988. Disponível em: <http://www.planalto.gov.br/ccivil_03/ constituicao/constituicaocompilado.htm>.

Acesso: 14 nov. 2017.

Brasil. Decreto no 98.181, de 26 de setembro de 1989. Declara de preservação permanente a floresta e demais formas de vegetação da área que descreve. Disponível em: <http://www2.camara.leg.br/legin/fed/ 
decret/1989/decreto-98181-26-setembro1989-439358-publicacaooriginal-1-pe.html>. Acesso: 14 nov. 2017.

Brasil. Lei no 10.257, de 10 de julho de 2001. Regulamenta os arts. 182 e 183 da Constituição Federal, estabelece diretrizes gerais da política urbana e dá outras providências. Disponível em: <http://www.planalto.gov.br/ccivil_03/leis/ LEIS_2001/L10257.htm>. Acesso em: 14 abr. 2017.

Brasil. Lei no 12.587, de 3 de janeiro de 2012. Institui as diretrizes da Política Nacional de Mobilidade Urbana; revoga dispositivos dos Decretos-Leis nos 3.326 , de 3 de junho de 1941, e 5.405, de 13 de abril de 1943, da Consolidação das Leis do Trabalho (CLT), aprovada pelo Decreto-Lei no 5.452, de $1^{\text {o }}$ de maio de 1943, e das Leis nos 5.917 , de 10 de setembro de 1973, e 6.261, de 14 de novembro de 1975; e dá outras providências. Disponível em: <http://www.planalto.gov. br/ccivil_03/_ato2011-2014/2012/lei/ 112587.htm>. Acesso em: 14 abr. 2017.

Brasil. Lei no 9.605, de 12 de fevereiro de 1998. Dispõe sobre as sanções penais e administrativas derivadas de condutas e atividades lesivas ao meio ambiente, e dá outras providências. Disponível em: <http://www.planalto.gov.br/ccivil_03/leis/ L9605.htm>. Acesso em: 14 abr. 2017.

Brasil. Lei no 9.795, de 27 de abril de 1999. Dispõe sobre a educação ambiental, institui a Política Nacional de Educação Ambiental e dá outras providências. Disponível em: <http://www.planalto.gov.br/ccivil_03/leis/ L9795.htm>. Acesso em: 14 abr. 2017.

Brasil. Lei no 9.985, de 18 de julho de 2000. Regulamenta o art. $225, \S 1^{\circ}$, incisos I, II, III e VII da Constituição Federal, institui o Sistema Nacional de Unidades de Conservação da Natureza e dá outras providências. Disponível em: <http://www.planalto.gov.br/ccivil_03/leis/ L9985.htm>. Acesso em: 14 abr. 2017.

Brumes, K. R. Cidades: (re)definindo seus papéis ao longo da história. Caminhos de Geografia, v. 2, n. 3, p. 47-56, 2001. Disponível em: <http://www.seer.ufu.br/ index.php/caminhosdegeografia/article/vie w/15260/8561>. Acesso em: 14 abr. 2017.

Brun, F. G. K.; Link, D.; Brun, E. J. 0 emprego da arborização na manutenção da biodiversidade de fauna em áreas urbanas. Revista da Sociedade Brasileira de
Arborização Urbana, v. 2, n. 1, p. 117-127, 2007. Disponível em: <http://www.revsbau. esalq.usp.br/artigos_revisao/revisao01.pdf>. Acesso em: 14 abr. 2017.

Campos, V. B. G.; Ramos, R. A. R. Proposta de indicadores de mobilidade urbana sustentável relacionando transporte e uso do solo. Anais do $1^{\text {o }}$ Congresso Luso-Brasileiro para o Planejamento Urbano, Regional, Integrado e Sustentável, 2005.

Carcereri, V.H.; Biondi, D.; Batista, A. C. Análise da cobertura arbórea das praças de Curitiba-PR. Revista Brasileira de Arborização Urbana, v. 11, n. 2, p. 12-26, 2016. <http://www.revsbau.esalq.usp.br/ artigos_cientificos/artigo545sn-

publicacao.pdf>. Acesso: 14 nov. 2017.

Carson, R. Primavera silenciosa. São Paulo: Gaia, 2010.

Carvalho, C. H. R. Mobilidade urbana sustentável: conceitos, tendências e reflexões. Brasília: IPEA, 2016. (Documento para discussão, 2194). Disponível em: <http://www.ipea.gov.br/portal/images/sto ries/PDFs/TDs/td_2194.pdf>. Acesso em: 14 nov. 2017.

Castro, A. A. B. C.; Melo, R. A.; Silveira, J. A. R.; Silva, G. J. A.; Lapa, T. A. Interfaces rodoviáriourbanas no processo de produção das cidades: estudo de caso do contorno rodoviário de João Pessoa, PB, Brasil. Ambiente Construído, v. 15, n. 3, p. 175-199, $2015 . \quad$ https://doi.org/10.1590/s167886212015000300034

Dias, G. F. Educação ambiental: princípios e práticas. São Paulo: Gaia, 1993.

Fraga, I. J.; Teruya, P. E. T.; Vieira Júnior, A. S. Os impactos ambientais urbanos no desenvolvimento da Cidade de Lagarto. Revista Eletrônica da Faculdade José Augusto Vieira, v. 6, p. 225-241, 2013. Disponível em: <http://fjav.com.br/revista/ Downloads/EdicaoEspecialdaPosLatoSensue mTerritorioDesenvolvimentoMeioAmbiente2 013/Artigo225_241.pdf>. Acesso em: 14 abr. 2017.

Garzon, L. F. N. Da maldição à bendição dos recursos naturais: um palimpsesto discursivo do Banco Mundial. Sustentabilidade em Debate, v. 4, n. 1, p. 295-300, 2013.

Goldemberg, J.; Lucon, O. Energia e meio ambiente no Brasil. Estudos Avançados, v. 21, n. 59, p.7-20, 2007. https://doi.org/ $10.1590 /$ S0103-40142007000100003 
Gonçalves, V. T. P.; Silva, K. C. A solidariedade como instrumento para o alcance do uso sustentável da água. In: Ferrer, G. R. (Coord.). Governança transnacional e sustentabilidade: estudos aplicados aos objetivos do desenvolvimento sustentável. Umuarama: UNIPAR, 2016. v. 2. p. 56-79.

Hajduk, S. The concept of a smart city in urban management. Business, Management and Education, v. 14, n. 1, p. 34-49, 2016. https://doi.org/10.3846/bme.2016.319

Hamel, E. H.; Grubba, L.S. Desafios do desenvolvimento sustentável e os recursos naturais hídricos. Revista Brasileira de Direito, v. 12, n. 1, p.100-111, 2016. Disponível em: <https://seer.imed.edu.br/ index.php/revistadedireito/article/view/11 11/841>. Acesso em: Acesso em: $14 \mathrm{abr}$. 2016.

Honda, S. C. A. L.; Vieira, M. C.; Albano, M. P.; Maria, Y. R. Planejamento ambiental e ocupação do solo urbano em Presidente Prudente (SP). urbe. Revista Brasileira de Gestão Urbana, v. 7, n. 1, p. 62-73, 2015. https://doi.org/10.1590/2175-3369.007. 001.A004

IBGE - Instituto Brasileiro de Geografia e Estatística. Áreas urbanizadas do Brasil. Rio de Janeiro: IBGE, 2017. (Série Relatórios Metodológicos, 44). Disponível em: <http://biblioteca.ibge.gov.br/visualizacao/li vros/liv100639.pdf>. Acesso em: 14 jul. 2017.

IBGE - Instituto Brasileiro de Geografia e Estatística. Paraíba >> João Pessoa. 2017. Disponível em: <http://cod.ibge. gov.br/7D7>. Acesso em: 25 jul. 2017.

João Pessoa. Lei Complementar no 029, de agosto de 2002. Institui o Código de Meio Ambiente do Município de João Pessoa e dispõe sobre o Sistema Municipal de Meio Ambiente - SISMUMA. Disponível em: <http://www.joaopessoa.pb.gov.br/portal/w p-content/uploads/2012/03/codi_meio_ ambi.pdf $>$. Acesso em: 25 jul. 2017.

João Pessoa. Lei no 12.101, de 30 de junho de 2011. Institui o Sistema Municipal de Áreas Protegidas de João Pessoa e dá outras providências. Disponível em: <http://www.joaopessoa.pb.gov.br/portal/w p-content/uploads/2015/02/Lei-12101-

2011-Sistema-Municipal-de-_reas-

Protegidas-SMAP.pdf>. Acesso em: 25 jul. 2017.
João Pessoa. Plano de Ação João Pessoa Sustentável. João Pessoa: Prefeitura Municipal, 2014. Disponível em: <http://www.joaopessoa.pb.gov.br/planode-acao-sustentavel/>. Acesso em: 25 jul. 2017.

Köppen, W. Versuch einer Klassifikation der Klimate, vorzugsweise nach ihren Beziehungen zurPflanzenwelt. Geographische Zeitschrift, v. 6, n. 12. p. 657-679, 1900.

Lacerda, A.V. Sustentabilidade: um olhar sobre a relação homem natureza. Revista Brasileira de Gestão Ambiental e Sustentabilidade, v. 4, n. 7, p. 15-19, 2017. https://doi.org/10.21438/rbgas.040702

Lacerda, N. P.; Souto, P. C.; Dias, R. S.; Souto, L. S.; Souto, J.S. Percepção dos residentes sobre a arborização da Cidade de São José de Piranhas-PB. Revista Brasileira de Arborização Urbana, v. 5, n. 4, p. 81-95, 2010. Disponível em: <http://www.revsbau. esalq.usp.br/artigos_cientificos/artigo116publicacao.pdf>. Acesso: 14 nov. 2017.

Lima Neto, E. M.; Bardelli-Da-Silva, M. Y.; Silva, A. R.; Biondi, D. Arborização de ruas e acessibilidade no Bairro Centro de CuritibaPR. Revista Brasileira de Arborização Urbana, v. 5, n. 4, p. 40-56, 2010. Disponível em: <http://www.revsbau.esalq.usp.br/ artigos_cientificos/artigo144-

publicacao.pdf>. Acesso: 14 nov. 2017.

Loboda, C. R.; Angelis, B. L. D. Áreas verdes públicas urbanas: conceitos, usos e funções. Ambiência, v. 1, n. 1, p. 125-139, 2005. Disponível em: <http://revistas.unicentro. br/index.php/ambiencia/article/view/157/ 185>. Acesso: 14 nov. 2017.

Lucena, A. D.; Cavalcante, J. N.; Cândido, G. A. Sustentabilidade do Município de João Pessoa: uma aplicação do barômetro da sustentabilidade. Revista Brasileira de Gestão e Desenvolvimento Regional, v. 7, n. 1, p.19-49, 2011. Disponível em: <http://www.rbgdr.net/revista/index.php/r bgdr/article/view/357/227>. Acesso em: 14 abr. 2017.

Malthus, T. Ensaio sobre o princípio da população como afecta o futuro progresso da humanidade com notas sobre as especulações de Mr. Godwin, M. Condorcet e outros escritores. Lisboa: EuropaAmérica, s.d. [1798]. (Livros de bolso, Ib 301). 
Martelli, A.; Delbim, L. R. Arborização urbana: percepção dos acadêmicos de Educação Física da Faculdade FMG Mogi Guaçu-SP. Journal of Health Sciences, v. 19, n. 2, p.154-159, 2017. Disponível em: <http://pgsskroton.com.br/seer/index.php/J HealthSci/article/view/3758/3672>. Acesso em: 14 nov. 2017.

Martins, M. F.; Cândido, G. A. Modelo de avaliação do nível de sustentabilidade urbana: proposta para as cidades brasileiras. urbe. Revista Brasileira de Gestão Urbana, v. 7, n. 3, p. 397-410, 2015. https://doi.org/ 10.1590/2175-3369.007.003.A009

Meadows, D. H.; Meadows, D. L.; Randers, J.; Behrens III, W. W. The limits to growth. New York: Universe Books, 1972. Disponível em: <http://www.donellameadows.org/wpcontent/userfiles/Limits-to-Growth-digitalscan-version.pdf>. Acesso em: 14 abr. 2017.

Melazo, G. C. A percepção ambiental e educação ambiental: uma reflexão sobre as relações interpessoais e ambientais no espaço urbano. Olhares \& Trilhas, v. 6, n. 6, p. 45-51, 2005. Disponível em: <http://www.seer.ufu.br/index.php/olhares etrilhas/article/view/3477/2560>. Acesso em: 14 abr. 2017.

Moura, J. D. P.; Hirata, C. A. A educação ambiental em debate. Revista Eletrônica Pro-Docência/UEL, v. 1, p. 2-11, 2013. Disponível em: <http://www.uel.br/ revistas/prodocenciafope/pages/arquivos/V olume5/1. HIRATA e MOURA.pdf $>$. Acesso em: 23 out. 2017.

Mucelin, C. A.; Bellini, M. Lixo e impactos ambientais perceptíveis no ecossistema urbano. Sociedade \& Natureza, v. 20, n. 1, p. 111-124, 2008. https://doi.org/10.1590/ S1982-45132008000100008

Novais, J. W. Z.; Farias, F. M.; Reis, N. M. S.; Marques, A.C.A.; Siqueira, A.Y.; Joaquim, T. O.; Ribeiro, B. V. A melhoria climática e conforto térmico proporcionado pela arborização em uma escola estadual em Várzea Grande-MT. Revista Brasileira de Arborização Urbana, v. 12, n. 3, p. 1-14, 2017. Disponível em: <http://www.revsbau. esalq.usp.br/teste/ojs-2.3.7/index.php/

REVSBAU/article/view/672/pdf>. Acesso em: 14 nov. 2017.

Oliveira-e-Silva, L. D. A operação de crédito internacional entre o Município de João Pessoa e o Banco Interamericano de Desenvolvimento. Revista da PGM, n. 5, p. 138-159, 2016-2017. Disponível em: <http://www.joaopessoa.pb.gov.br/portal/w p-content/uploads/2016/04/revista-PGM2016.pdf\#page $=138>$. Acesso em: $14 \mathrm{abr}$. 2017.

ONU - Organização das Nações Unidas. World urbanization prospects: the 2011 revision. New York: UNO, 2012. Disponível em: $\quad<$ http://esa.un.org/unpd/wup/ index.htm>. Acesso em: 14 abr. 2017.

Paraíba. Lei no 6.818, de 16 de dezembro de 1999. Concede o título de Cidade Verde à Cidade de João Pessoa. Disponível em: <http://sapl.al.pb.leg.br:8080/sapl/sapl_doc umentos/norma_juridica/6583_texto_integra l>. Acesso em: 14 abr. 2017.

Paraíba. Lei Complementar no 59, de 30 de dezembro de 2003. Cria a Região Metropolitana de João Pessoa, o Fundo de Desenvolvimento Metropolitano e dá outras providências. Disponível em: <http://sapl.al.pb.leg.br:8080/sapl/sapl_doc umentos/norma_juridica/5579_texto_integra l>. Acesso em: 14 abr. 2017.

Paraíba. Lei Complementar no 90, de 23 de julho de 2009. Dá nova redação ao art. $1^{\circ}$, do Capítulo I, da Lei Complementar no 59, de 30 de dezembro de 2003, e dá outras providências. Disponível em: <http://sapl.al.pb.leg.br:8080/sapl/sapl_doc umentos/norma_juridica/9379_texto_integra l>. Acesso em: 14 abr. 2017.

Paraíba. Lei Complementar no 93, de 11 de dezembro de 2009. Dá nova redação ao art. 1ํ, da Lei Complementar no 59 , de 30 de dezembro de 2003, e dá outras providências. Disponível em: <http://sapl.al.pb.leg.br: 8080/sapl/sapl_documentos/norma_juridica /9427_texto_integral>. Acesso em: 14 abr. 2017.

Paraíba. Lei Complementar no 116, de 21 de janeiro de 2013. Institui a Região Metropolitana do Vale do Mamanguape com sede na Cidade de Mamanguape e dá outras providências. Disponível em: <http://sapl.al.pb.leg.br:8080/sapl/sapl_doc umentos/norma_juridica/10646_texto_integr al>. Acesso em: 14 abr. 2017.

Paraíba. Decreto no 35.195, de 23 de julho de 2014. Cria o Refúgio de Vida Silvestre da Mata do Buraquinho, no Município de João Pessoa. Disponível em: <http://static. paraiba.pb.gov.br/2014/07/Diario-Oficial24-07-2014.pdf>. Acesso em: 14 abr. 2017. 
Passos, L. A.; Silveira, F. A.; Pita, A. L. L. R.; Braga, C. F. C.; Silveira, J.A. R. Processo de expansão versus sustentabilidade urbana: reflexão sobre as alternativas de deslocamento na Cidade de João Pessoa, PB. urbe. Revista Brasileira de Gestão Urbana, $\begin{array}{lll}\text { v. } 4, \quad \text { p. } 1, \quad \text { p } 4-59, & 2012 .\end{array}$ https://doi.org/10.7213/urbe.6029

Pizzol, K. M. S. A.; Ribeiro, E. L. O cotidiano urbano: uso e mobilidade nos passeios públicos em quatro bairros de João PessoaPB. Geografia, v. 14, n. 2, p. 145-156, 2005. Disponível em: <http://www.uel.br/ revistas/uel/index.php/geografia/article/vie w/6690/6035>. Acesso em: 14 nov. 2017.

Rede Nossa São Paulo. Programa Cidades Sustentáveis. 5. ed. São Paulo, 2012. Disponível em: <http://www.cidades sustentaveis.org.br/downloads/publicacoes/ publicacao-programa-cidades-

sustentaveis.pdf $>$. Acesso em: 14 abr. 2017.

Ribeiro, F.A. B.S. Arborização urbana em Uberlândia: percepção da população. Revista da Católica, v. 1, n. 1, p. 224-237, 2009. Disponível em: <http://www.catolica online.com.br/revistadacatolica2/artigosv1n 1/20_arborizacao_urbana.pdf>. Acesso em: 14 nov. 2017.

Rio, V. D.; Oliveira, L. Percepção ambiental: a experiência brasileira. 2. ed. São Paulo: UFSCar, Studio Nobel, 1999.

Rocha, C. M. R. S.; Gadelha, D. P.; Almeida, S. R. S. O desenvolvimento de políticas públicas e a influência do capital social na construção do desenvolvimento local sustentável. Revista Brasileira de Gestão Ambiental e Sustententabilidade, v. 4, n. 8, p. 463-474, $2017 . \quad$ https://doi.org/10.21438/rbgas. 040818

Romeiro, A. R. Desenvolvimento sustentável: uma perspectiva econômico-ecológica. Estudos Avançados, v. 26, n. 74, p. 65-92, 2012 https://doi.org/10.1590/S010340142012000100006

Schuch, M. I. S. Arborização urbana: uma contribuição à qualidade de vida com uso de geotecnologias. Santa Maria: Universidade Federal de Santa Maria, 2006. (Dissertação de mestrado). Disponível em: <http://repositorio.ufsm.br/bitstream/handl e/1/9600/Mara Ione.pdf>. Acesso em: 14 abr. 2017.

Sell, J. B. V.; Haupenthal, V. B. Gestão sustentável e uso eficiente dos recursos naturais fatores determinantes para a manutenção da espécie humana. In: FERRER, G. R. (Coord.). Governança transnacional e sustentabilidade: estudos aplicados aos objetivos do desenvolvimento sustentável. Umuarama: UNIPAR, 2016. v. 2. p. 180-189.

Silva, K. A distribuição dos espaços públicos em Belo Horizonte: uma análise sob a ótica do direito à cidade e do planejamento urbano. Revista de Direito da Cidade, v. 9, n. 4, p. $1586-1605,2017$. https://doi.org/ $10.12957 /$ rdc. 2017.29263

Souza, J. F.; Silva, R. M.; Silva, A. M. Influência do uso e ocupação do solo na temperatura da superfície: o estudo de caso de João PessoaPB. Ambiente Construído, v. 16, n. 1, p. 2137, 2016. https://doi.org/10.1590/s167886212016000100058

Stipp, N. A. F.; Stipp, M. E. F. Análise ambiental em cidades de pequeno e médio porte. Geografia, v. 13, n. 2, p. 23-36, 2004. Disponível em: <http://www.uel.br/ revistas/geografia/v13n2/2.pdf >. Acesso em: 14 abr. 2017.

Stoffel, J. A.; Colognese, S. A. O desenvolvimento sustentável sob a ótica da sustentabilidade multidimensional. Revista FAE, v. 18, n. 2, p. 18-37, 2015. Disponível em: <https://revistafae.fae.edu/revistafae/ article/view/48/44>. Acesso em: 14 abr. 2017.

Sushinsky, J. R.; Rhodes, J. R.; Shanahan, D. F.; Possingham, H. P.; Fuller, R. A. Maintaining experiences of nature as a city grows. Ecology and Society, v. 22, n. 3, art. 22, 2017. https://doi.org/10.5751/ES-09454220322

Thomson, J. M. Reflections on the economics of traffic congestion. Journal of Transport Economics and Policy, v. 32, part 1, p. 93-110, 1998. Disponível em: <http://www.bath.ac.uk/e-journals/jtep/ pdf/Volume_32_Part_1_93-112.pdf>. Acesso em: 14 abr. 2017.

Topp, H. H. A critical review of current illusions in traffic management and control. Transport Policy, v. 2, n. 1, p. 33-42, 1995. https://doi.org/10.1016/0967-070X(95) 93244-S

Trigueiro, A. Meio ambiente no século 21: 21 especialistas falam da questão ambiental nas suas nas suas áreas de conhecimento. Rio de Janeiro: Sextante, 2003.

Verhetsel, A. The impact of planning and infrastructure measures on rush hour congestion in Antwerp, Belgium. Journal of 
Transport Geography, v. 9, n. 2, p. 111-123, 2001. $\quad$ https://doi.org/10.1016/S09666923(00)00041-7

Vieira, J. S. R. Cidades sustentáveis. Revista de Direito da Cidade, v. 4, n. 2, p. 1- 39, 2012. https://doi.org/10.12957/rdc.2012. 9710

Weiss, M. C.; Bernardes, R. C.; Consoni, F. L. Cidades inteligentes como nova prática para o gerenciamento dos serviços e infraestruturas urbanos: a experiência da cidade de Porto Alegre. Revista Brasileira de Gestão Urbana, v. 7 , n. 3, p. 310-324, $2015 . \quad$ https://doi.org/10.1590/21753369.007.003.A001

Ximenes, D.S.S. A evolução da sustentabilidade ambiental urbana e as interferências da ética Revista LABVERDE, n. 2 , p. 82-80, 2011. https://doi.org/ 10.11606/issn.2179-2275.v0i2p62-80

Yu, Z.; Guo, X.; Jørgensen, G.; Vejre, H. How can urban green spaces be planned for climate adaptation in subtropical cities? Ecological Indicators, v. 82, p 152-162, 2017. https://doi.org/10.1016/j.ecolind. 2017.07.002 